Financing and implementation of adaptation measures to climate change along the Spanish coast.

\author{
U. López-Dóriga $^{1 *}$, J.A. Jiménez ${ }^{1}$, A. Bisaro ${ }^{2}$, J. Hinkel $^{2}$ \\ 1 Laboratori d'Enginyeria Marítima, Universitat Politècnica de \\ Catalunya·BarcelonaTech, c/Jordi Girona 1-3, Campus Nord ed D1, 08034 Barcelona, \\ Spain. \\ ${ }^{2}$ Global Climate Forum, Neue Promenade 6, 10178 Berlin, Germany \\ * corresponding author (uxia.lopez-doriga@upc.edu)
}




\section{Financing and implementation of adaptation measures to climate change along the Spanish coast.}

4

\section{Abstract}

Understanding how we are adapting to climate change in coastal areas is an essential issue in the long-term coastal planning. While most of existing studies focus on mapping the current state of adaptation plans, there is a significant lack of studies on the current implementation of adaptation strategies. This study addresses this challenge by assessing how coastal adaptation is being financed and implemented in Spain. In the absence of a detailed roadmap for implementing the Spanish Strategy for Coastal Adaptation to Climate Change, we have analysed how adaptation has been and is currently being funded; which the rationale for investments along the territory is; how adaptation investments compare to regular coastal protection costs; and assessed when implemented measures are really adaptation ones. Our results show that the financing source clearly conditions the type of measures implemented, with those funded under the Environment Promotion Plan for Climate Change Adaptation (PIMA Adapta initiative) being dominated by classical coastal engineering actions, whereas ecosystem-related actions are mostly funded under the LIFE programme. In territorial terms, the Mediterranean coastal regions present the most important problems under current conditions and attract most of the funding. Most of the funded actions have been designed to solve current coastal problems, and although they indirectly contribute to adaptation by improving the coastal base status, they are not specifically designed for climate change. This misuse of the concept of adaptation measure will tend to the society to be overconfident about adopted actions whereas we are not progressing to real adaptation. To overcome this risk, it is necessary to have a clear roadmap for implementing adaptation measures together a proper financing structure.

\section{Key words}

Climate change adaptation, coastal protection, coastal management, national adaptation strategy, Spain. 


\section{Introduction}

Climate adaptation has become a core focus in the political agenda, with the goal of enhancing preparedness and the capacity to cope with climate change impacts (Biesbroek et al., 2010; Khan and Roberts, 2013). Indeed, EU Member States have started to develop national adaptation strategies requiring physical, social, and institutional measures to adapt to climate change, given the recognition that mitigation alone is insufficient to prevent impacts (Biesbroek et al., 2010).

While adaptation strategies to climate change are necessary everywhere where significant impacts are expected, coasts are areas of special interest since they concentrate a series of characteristics related to their susceptibility to natural hazards, their exposure in terms of natural and human values, and the fact to be directly subjected to one of the most relevant climate-related changes, the accelerated rise in sea level (see e.g. Nicholls et al., 2007). As a consequence, coastal communities and infrastructures are likely to be affected and, therefore, coastal adaptation will be required on almost all populated coastlines in the world (Nicholls, 2011). In fact, the European Climate Change Adaptation Strategy recognises coastal areas as one of the most at risk being priority areas to climate change adaptation (European Commission, 2013). In this sense, many studies state that adaptation costs would be lower than damage costs without adaptation for most developed coasts. As an example, the economic cost of coastal flooding has been estimated at 18 billion $€$ under a scenario of $50 \mathrm{~cm}$ of sea level rise, but adaptation may significantly reduce changes to 1 billion $€$ /year (EEA, 2008). These issues are not limited to Europe, without adaptation, $0.2-4.6 \%$ of the worldwide population is expected to be flooded annually in 2100 under $25-123 \mathrm{~cm}$ of global mean sealevel rise, with expected annual losses of $0.3-9.3 \%$ of the global gross domestic product (Hinkel et al., 2014).

In spite of this, although numerous studies on coastal adaptation have been performed in recent years, most of them have focused on mapping the current state of adaptation plans (e.g. Araos et al., 2016; Gibbs, 2019; Pearce et al., 2018; Woodruff and Reagan, 2019), while a noticeable lack of studies on the implementation of adaptation does exist (e.g. Mimura et al., 2014). Moreover, governments at all levels are expressing their intention to adapt, but not much progress is being made in terms of implementation (Berrang-Ford et al., 2011). One possible explanation is that the associated political risk of adaptation could act as a constraint (Ford et al., 2011; Gibbs, 2016; Lesnikowski et al., 2015). In fact, a review on early 
implementation of adaptation plans by local governments has shown that they mostly adopt a reactive or event-driven approach, with a main focus on climate variability and current weather extremes rather than long-term climate change (Mimura et al., 2014).

Furthermore, there is an increasing recognition that barriers to coastal adaptation are not technical or economic, but are largely financial and social (Hinkel et al., 2018). Indeed, while an adaptation finance gap is substantial across all sectors (UNEP, 2016), it is significant for coastal adaptation in particular, where currently, governments appear to be meeting only a fraction of the costs needs to ensure flood safety (Nicholls et al., 2019). Financing coastal adaptation is challenging for several reasons. First, coastal adaptation provides long-term stochastic benefits, whereas the costs of provision are large and upfront (Bisaro and Hinkel, 2018), putting pressure on strained public budgets that need to consider opportunity costs of investment (Penning-Rowsell and Priest, 2015). Second, coastal adaptation involves highvalue coastal real estate, and adaptation measure values can affect amenity values, for example, sea walls may decrease the quality of ocean views, giving rise to rent-seeking behaviour by vested interests in blocking such measures (Beatley, 2012). Third, coastal areas are subject to multiple uses and diverse stakeholder interests. The resulting governance structures often result in overlapping or unclear public responsibilities (Storbjörk and Hedrén, 2011), which act as a barrier to financing. Yet while the current literature has described and enumerated such barriers, often in individual case studies (Eisenack et al., 2014), less attention is dedicated to analysing coastal adaptation financing decisions at the national level to, for example, identify patterns in such decisions and the underlying drivers of such barriers. Therefore, a better understanding of the adaptation finance is necessary to better tailor appropriate solutions, as the overall expenditures for coastal adaptations will rise with the sea level, and must compete for resources with other concerns (Moser et al., 2018). As a consequence of all this, it seems clear that coastal adaptation needs to start earlier than anticipated to provide time to engage stakeholders, to enable effective decision making and to implement measures (Haasnoot et al., 2019).

Within this context, Spain adopted the National Adaptation Plan to Climate Change (PNACC) and the Spanish Strategy for Coastal Adaptation to Climate Change (CAS hereinafter) in 2006 and 2016, respectively. This is a statutory and multi-sectorial national planning strategy for climate change adaptation of coastal areas, with the aim of assisting in the decision-making process to plan for, implement and monitor adaptation actions (Losada et al., 2019). Thus, since Spain is starting to implement coastal adaptation actions, the assessment of these early- 
stage investments is important to put them in the context of long-term coastal planning. In this sense, it has to be considered that most of climate adaptation efforts reported worldwide deal with partial solutions and approaches to climate adaptation, rather than more full-scale implementation (see Mimura et al., 2014).

Understanding coastal adaptation financing and implementation provides context for this paper, where the case of Spain is particularly interesting since it is considered as one of the top countries in Europe in terms of climate adaptation initiatives as well as in investments in coastal protection in general (Policy Research Corporation, 2009a; Lesnikowski et al., 2015, 2016). Thus, it will be relevant to assess to what extent the implemented measures are consistent with the established policy goals and plans. In the absence of an approved roadmap to implement measures included in the CAS, it is worthy to identify the existence of a rationale behind the spatial distribution of investments at this early stage. As previously mentioned, Mimura et al. (2014) concluded that many early implementations of adaptation plans have a main focus on climate variability and extremes rather than long-term climate change. In this context, it is also relevant to assess if current implementation measures along the Spanish coast are really adaptation measures, or their targets are current coastal problems but financed under the umbrella of adaptation financing initiatives (PIMA-Adapta) as a matter of opportunity. This should be noted in the time evolution of total investments in coastal protection in the near future.

To our knowledge, no previous studies have provided an in-depth analysis of current investments in coastal adaptation measures for climate change at national level in general, and along the Spanish coastline in particular. Therefore, the main goal of this paper is to assess the current progress of Spain in implementing coastal adaptation measures to climate change. To this end, we have analysed how Spain is currently financing coastal adaptation; which measures within the CAS are currently being implemented; the extent to which measures already implemented are actually adaptation measures; and how the current investments in coastal adaptation measures compare with the occurrences of current "regular" coastal protection measures (without climate change). Finally, based on this analysis, we will provide policy recommendations on possible adjustments and the investment pattern required for an efficient long-term implementation of adaptation measures for climate change along the Spanish coast. 


\section{Study area}

\subsection{Study area}

The Spanish coastline (Figure 1) is approximately 7,900 km long, and comprises a high diversity of coastal environments including cliffs, rocky coasts, embayed beaches, long beaches, estuaries, swamps, dunes and deltas, along three main climate areas (Mediterranean, Temperate-Atlantic, Subtropical-Canary Islands). In general terms, the Mediterranean area has the largest abundance of beaches, whereas the Atlantic area presents the largest extension of cliff areas.

\section{$<$ Figure $1>$}

From an administrative standpoint, this coastline extends along 10 autonomous communities and 2 autonomous cities, comprising 20 coastal provinces and 487 municipalities. Approximately $40 \%$ of the Spanish coastline is urban, $7 \%$ is occupied by port facilities, $3 \%$ is occupied by industrial facilities and $8 \%$ is used for farming (Orts, 2016). The Spanish coast is also an area of high concentration of population, with approximately $45 \%$ of the national population living in coastal municipalities, which only represent approximately $7 \%$ of the territory. Table 1 shows an overview of the main physical and socioeconomic indicators of the Spanish coastal zone.

\section{$<$ Table $1>$}

The combination of a long coastline, where inundation and erosion-induced problems are already frequent under current climate conditions (e.g. Del Río et al., 2012, 2013; Jiménez et al., 2012; Jiménez and Valdemoro, 2019; Rodríguez-Ramírez et al., 2003; Sanjaume and Pardo, 2005) and high human pressures concentrating values along the coast, makes the Spanish coastline a vulnerable environment to climate change-induced flooding and erosion. Nevertheless, coastal vulnerability significantly varies along the territory as a function of physical and socioeconomic characteristics. A national assessment of the expected impacts induced by climate change along the Spanish coast is given by Losada et al. (2014), who found that coastal systems were especially sensitive to the effects of sea-level rise and other factors such as rising water surface temperatures, acidification, and changes in storm surge. The obtained results have been used by the Spanish Office of Climate Change (OECC) to identify adaptation needs in the Spanish coastline as well as the required actions. Additional 
site specific assessments of sea level rise-induced impacts along the Spanish coasts can be found in Enríquez et al. (2017), Jiménez et al. (2017), López-Dóriga et al. (2019), MartínezGraña et al. (2018), Toimil et al. (2018), among others.

\subsection{Administrative framework for coastal risk and climate change adaptation}

Formally, in Spain, the OECC holds the competences in adaptation to climate change policymaking, assessment, and implementation at the national level, among other climate changerelated issues. These aspects included in the responsibilities of the Secretary of Environment within the Ministry for the Ecological Transition (MITECO hereinafter, formerly Ministry of Agriculture and Fisheries, Food and Environment).

In 2006, OECC developed the PNACC, which is the framework for coordinating the Spanish public administration to carry out actions to evaluate the impacts, vulnerability, and adaptation to climate change in Spain (OECC, 2006). This plan is implemented through work programmes, where priority activities to be addressed are covered. The current programme (WP3) was adopted in 2013 (OECC, 2014).

Competences on management in the coastal zone in Spain are distributed between different administrations, i.e. central government, autonomous communities and municipalities, with the central government playing the most important role. The autonomous communities have the administrative competence for urban planning in the coastal zone, whereas the national General Directorate for Sustainability of the Coast and the Sea (DGSCM hereinafter) is the administrative body for ruling and managing the maritime-terrestrial public domain. The DGSCM lays out and implements the coastal management policy that is applied in situ by their administration's peripheral services, known as coastal demarcations, to address identified coastal problems/issues along the Spanish coast. Thus, the central government has the competences in coastal protection along the entire Spanish coast and, in this sense, the funding for coastal protection is provided through the DGSCM.

With regards to the coastal zone, as a result of one of the obligations of the Law 2/2013 for the protection and sustainable use of coasts and amendment of the Spanish Coastal Act 22/1988, the DGSCM developed the Spanish Strategy for Coastal Adaptation to Climate Change (CAS hereinafter, as mentioned above). This national strategy was officially approved after a positive strategic environmental assessment in 2016 (DGSCM, 2016). It indicates different degrees of coastal vulnerability and risk along the entire Spanish coastline, 
and it identifies measures to address potential effects (Losada et al., 2019). This strategy is being downscaled to the regional level by developing specific strategies for coastal regions, in a process controlled by autonomous regions. In addition to this, the DGSCM has also developed several (five already done, two in progress) dedicated strategies to the protection of the coast in areas currently experiencing large erosion problems. These strategies diagnose the problem, prioritise areas to be protected, and propose different alternatives to address the problem, which are in line with measures considered in the CAS.

\section{Materials and methods}

\subsection{General methodological framework}

As it has been already mentioned, the lack of comprehensive studies about implementation of adaptation measures at large scale, the characteristics of the information to be analysed, and the type of data to be analysed have driven us to design a methodological framework to be used in the analysis. The practical goal of the methodology is to get a country profile on the implementation of coastal adaptation measures. The proposed methodological framework serves to answer different questions contributing to get such profile and it is schematised in Figure 2. It consists of three main steps: (i) the creation of a database on implemented adaptation measures; (ii) the compilation of data to characterize regions where we are adapting and to describe the context of current investments in coastal protection; and (iii) the analytical module where data are analysed to answer target questions.

\subsection{Data compilation}

The first part of the methodology consists of the compilation and analysis of investments in adaptation measures along the Spanish coast that have been explicitly (and officially) designed to address adaptation to climate change. To this end, we have built a database of measures implemented along the different coastal regions of Spain, where we compiled the types of measures, locations, budgets and funding agencies. There are two main financial sources for coastal adaptation actions in the Spanish coastal zone: the central government 
through the PIMA Adapta programme, established under the PNACC, and the EU, through the LIFE programme.

The PIMA Adapta programme was implemented in 2015 by the Spanish government to fund adaptation projects related to water resources, coastal areas, and biodiversity in National Parks. It is operated by MITECO through the OECC. With respect to coastal adaptation, this initiative covers a wide range of actions to restore coastal habitats and stabilise the shoreline, with the objective of reducing vulnerability to the effects of climate change. It also includes information regarding resources and uses of the territory, as well as vulnerability studies on the coast for developing regional adaptation plans. PIMA Adapta actions in coastal areas are managed by two different entities. In particular, adaptation measures implemented in the Maritime-Terrestrial Public Domain are handled by DGSCM. In contrast, the budget allocated to developing detailed vulnerability studies, as well as regional adaptation strategies, is distributed to coastal autonomous communities.

Data on investments through PIMA Adapta programme have been collected from information provided by the OECC, as well as from analysing information provided by the DGSCM on the budget distribution per fiscal year. In the latter case, only measures directly funded through the PIMA Adapta programme are accounted for. Thus, for instance, a given type of adaptation measure, such as beach nourishment, can be funded through the regular annual budget, or through PIMA Adapta. Table 2 shows some examples of different adaptation measures conducted by the DGSCM through the PIMA Adapta programme.

$<$ Table $2>$

The second major source for funding adaptation measures to climate change is the LIFE programme. This is an EU programme for the environment, nature, and climate action, and has funded more than 2,600 projects since 1992. Its overall objective is to contribute to the implementation, updating, and development of environmental policy and legislation for the EU by co-financing relevant projects. This is a competitive process, and the European Commission launches periodic calls for proposals under selected "priority areas" according to a work programme. Usually, the EU co-financing rate is 50\%, except in cases where projects focus on concrete conservation actions for priority species or habitats, where co-financing can 
increase up to $75 \%$. The beneficiaries are public and private bodies and the objectives, tasks, and actions for different involved stakeholders, as well as financial responsibilities, are established through a grant agreement. These beneficiaries contribute to the remaining part of the budget.

To identify LIFE-projects that directly contribute to adaptation to climate change in Spain, the LIFE programme database was searched for projects in Spain with selected keywords (for example, coastal areas, adaptation, climate change). In this work, we only consider LIFEfunded projects from 2010 onwards, covering the period of PIMA Adapta implementation as well as some additional years during which society became more concerned regarding potential impacts of climate change. In this respect, the second work programme (WP2) of the PNACC, which is considered as a significant step for systematically addressing adaptation to climate change in Spain (OECC, 2009) was adopted in 2009. The LIFE projects classified here as investments in adaptation in the Spanish coastal zone are listed in the supplementary material, Table S1. We report on the sum of the EU contribution and co-financing from the partners.

In addition to collecting data on the funding of coastal adaptation measures, we also compiled data on the current expenditures on protection, so as to characterise the current needs to maintain, protect, and preserve the Spanish coast (referred to as regular budget). These expenditures are covered by the Spanish government through the DGSCM. Data have been collected from information provided by the DGSCM and the national general budgets on budget distribution per fiscal year and per coastal protection objective. These yearly budgets included an amount to be used for emergencies, usually associated with measures to cope with damages induced by the impact of storms. Since 2014, the DGSCM has launched yearly programs, called Plan Litoral, for funding emergency measures to repair storm-induced damages along the Spanish coast. This program is only launched in years where the frequency or intensity of storms induce very significant damage along the Spanish coast, as was the case in 2014, 2015, 2017, and 2018. Expenditures in this program have been compiled from information provided by the DGSCM characterising the current investment needs to compensate for storm-induced damages under current climate conditions.

\subsection{Data analysis}


The data analysis focuses on identifying the dominant measures and geographical rationales for investments during the first years of the implementation of the PNACC. This is completed by characterising the current context of expenditures for maintaining and preserving the Spanish coastal zone during the last decade, from 2010 to 2018.

Investments in adaptation measures were classified according to the CAS, which is consistent with the International Panel on Climate Change (IPCC) AR5 (Noble et al., 2014). It classifies actions into three major categories: (i) structural-physical, (ii) social, and (ii) institutional, and into three sub-categories based on the typology and purpose: (i) protection, (ii) accommodation and (iii) retreat. In total, the CAS considers 26 different adaptation actions, which are classified according to these two criteria (supplementary material, Table S2). Measures already implemented along the Spanish coast and funded under PIMA Adapta and LIFE projects were classified according to these criteria.

Finally, measures were grouped in more generic classes to simplify the classification (see supplementary material, Table S3), including the combination of different options (mixed type), and a class for actions where their typology was not specified (without specifying the type). The distribution of expenditures per type for each project is determined according to the provided description. When it consists of more than one measure, the investment is assigned the following budget details. In the case of projects executed in different coastal regions (this is especially applicable to LIFE projects), the budget is split accordingly, to obtain corresponding regional values.

To put investments in coastal adaptation measures into a general context, we compare them with current expenditures in coastal protection during the last decade. Current expenditures in coastal protection by the DGSCM were classified in terms of their main official objectives. To make a consistent comparison to investments in coastal adaptation, we identified expenditures associated with objectives directly covered by the CAS (see supplementary material, Table S4).

To characterise the geographical distribution of investments in coastal adaptation, the compiled data are aggregated within each coastal region. Thus, regional values of total investments and investments per type of measure were obtained for PIMA Adapta and LIFE projects.

To investigate the rationale behind the geographical distribution, we analyse the relationship between the distribution of investments and selected regional indicators characterising spatial 
scale, economic importance, and coastal vulnerability. These indicators are the coastline length and GDP of the coastal provinces of each region, whereas the vulnerability of each region is characterised by using an integrated value of the coastal vulnerability index (CVI), as calculated by López-Royo et al. (2016). This is a slightly modified version of the Gornitz and Kanciruk (1989) index to characterize the vulnerability of coastal areas to coastal hazards including SLR, particularly due to erosion and/or inundation. This is formulated in terms of a series of variables such as geomorphology, coastal slope, shoreline evolution, relative sea level rise, wave climate and tidal range.

\section{Results}

\subsection{Investments in coastal adaptation}

The total investment in coastal adaptation to climate change during the analysed period (2010-2018) in the Spanish coastal regions has been estimated at $56 \mathrm{M} €$, from which 57\% was funded by the Spanish national initiatives under the PIMA Adapta program. The remaining parts were funded through LIFE projects, which are co-funded by the EU Commission and Spanish administration (local, regional and national). If we normalise these investments for the covered period by each source, the average current investment in coastal adaptation in Spain is approximately $8 \mathrm{M} €$ /year using national funds, and $2.6 \mathrm{M} €$ /year using LIFE project funds (considering both EU and partner contributions).

Figure 3 shows the distribution of such investments according to the type of measures along the Spanish coast. Approximately $40 \%$ of the total budget was dedicated to social and institutional measures. Here, the main efforts were devoted to financing research projects and studies aimed at developing regional adaptation plans and analysing adaptation options $(11.8 \%)$, as well as at evaluating services provided by coastal ecosystems (14.2\%). Although the analysed period covers the early stages of the funding strategy, approximately half of the total budget was used to implement structural measures $(44.9 \%)$ dominated by nature-based solutions and soft measures, representing $23.1 \%$ and $14.7 \%$ of the investment, respectively.

One interesting result is that the types of measures funded differ strongly between the two funding sources. Structural measures funded through the national adaptation plan consist of soft measures (mostly beach nourishment), nature-based solutions and hard defences $(21.6 \%$, $14.4 \%$, and $8.7 \%$, respectively). When these type of measures are considered under the 
umbrella of LIFE funding, the role played by nature-based measures increases up to $34.6 \%$, that of soft measures decreases down to 5.5\%, and no hard measures are considered.

With respect to social and institutional actions, there is also a significant difference between funding sources. The LIFE funding clearly promotes this type of social and institutional actions, with approximately $60 \%$ of the investment dedicated to projects to evaluate and protect ecosystem services and to define protected areas. In contrast, $24.2 \%$ of the national funding was purely for social actions, with an absence of institutional measures. Approximately $15.5 \%$ of funds were not associated with specific types of measures, owing to a lack of relevant information.

\subsection{Geographical distribution of investments in coastal adaptation}

The geographical distribution of the investments in coastal adaptation along the Spanish coastline is shown in Figure 4. Most of the funding was allocated to the Mediterranean coastal zone, with the largest three regions (Andalusia, Catalonia and Valencia) concentrating approximately $73 \%$ of the regional investment distributed among the coastal regions $(56 \%$ if total investment, as $12.83 \mathrm{M} €$ are destined for measures that are not associated to a specific region). This is partially owing to the fact that these regions have successfully attracted LIFE funds. As an example of this, approximately $70 \%$ of the total investment in Andalusia and Catalonia has been obtained through LIFE funding, with important coastal adaptation projects such as LIFE-Adaptamed and LIFE-Pletera having been implemented. These regions also concentrate the largest investment $(56 \%)$ of the national PIMA Adapta program along the Spanish coastline since 2015. In contrast, Murcia, Ceuta, and Melilla present the lowest investments in coastal adaptation, with all actions being supported through national funds.

\section{$<$ Figure $4>$}

Figure 5 shows the distribution of investments and selected regional indicators. When investments in a region are related to coastline length, there is an apparent direct relationship, i.e. the larger the shoreline, the larger the investment. However, when all data are considered, 
they are not significantly statistically correlated (Figure 5A). This lack of correlation is caused by two groups of regions which depart from this general trend: (i) regions with a highlyindented coastline which results in a very large length (Galicia, Canary, and Balearic Islands), and (ii) regions comprised by an autonomous city, which results in a very short length (Ceuta and Melilla). When these regions are removed from the analysis, a very strong correlation is obtained $\left(r^{2}=0.94\right)$ between investment and coastline length.

When investments are related to the economic importance of coastal provinces within each region, again a direct relationship is noted, i.e., the larger the regional coastal GDP, the larger the investment (Figure 5B). In this case, the entire dataset follows the trend and they show a moderate correlation $\left(\mathrm{r}^{2}=0.57\right)$. In spite of this, Andalusia behaves as an outlier, receiving an investment much larger than expected according to its GDP. If this region is removed, the obtained correlation between investment and coastal GDP significantly improves $\left(\mathrm{r}^{2}=0.91\right)$.

Finally, investments in coastal adaptation in each region were related to an overall measure of coastal vulnerability. To this end, we have used the previous results obtained by López-Royo et al. (2016) who characterised the vulnerability of the continental Spanish coastline (excluding islands and autonomous cities in North Africa) by using a modified version of the CVI. Figure 5C shows the investments in each region versus their average CVI values. As can be seen, regions with the largest investments (Andalusia, Catalonia, and Valencia) are classified as high or very-high vulnerability coastlines, as these areas contain the largest extensions of uninterrupted sandy beaches. Despite the fact that this vulnerability computation was not used as a decision criterion for distributing funding, the investment in each region is strongly correlated to its vulnerability degree $\left(r^{2}=0.77\right)$. In other words, the larger the coastal vulnerability, the larger the investment.

\subsection{Investments in coastal protection}

$<$ Figure $5>$

To put investments in coastal adaptation measures into a general context, expenditures in coastal protection in Spain during the last decade are analysed.

Figure 6 shows the evolution of annual expenditures in coastal measures funded by the DGSCM since 2010. There is a significant drop in total expenditures after 2010, decreasing 
by about 120 million $€$ in just two years, to reach a nearly constant annual investment in regular coastal actions of $61 \mathrm{M} € /$ year since 2012. Here "regular" means expenditures without including storm recovery investment specific budget items (Plan Litoral). However, most of this sharp decrease (approximately 70\%, $84 \mathrm{M} €$ in two years) was incurred under an objective of "improve and ensure the public and free use of the coast", which is not directly related to the measures covered by the CAS (see supplementary material, Table S4). If we only retain the annual expenditures in measures related to adaptation options included in the CAS (see supplementary material, Table S4), the current investments in coastal protection were not so severely affected (blue line in Figure 6).

Since 2014, the DGSCM budget has stabilised at a value approximately 55\% lower than in 2010 (Figure 6), with an average annual expenditure of $64 \mathrm{M} € /$ year. From that $64 \mathrm{M} € /$ year, approximately $40 \mathrm{M} € /$ year is devoted to coastal protection projects related to options included in the CAS (supplementary material, Table S4). In addition, during this period, the DGSCM has also had an average annual investment of $26 \mathrm{M} € /$ year in emergency measures. Considering both contributions, i.e. coastal protection measures including Plan Litoral, the average annual investment of the DGSCM under current conditions to maintain and preserve the Spanish coast is approximately $66 \mathrm{M} € /$ year.

\section{Discussion}

In this work, we have done a first evaluation of current expenditures in adaptation measures to climate change along the Spanish coast. Until present, most of activities related to coastal adaptation in Spain were related to assessing impacts and vulnerability, capacity building actions and developing plans and strategies (e.g. European Commission, 2018). In this respect, the number of adaptation initiatives and actions to climate change placed Spain as one of the top countries in Europe and even worldwide (Lesnikowski et al., 2015, 2016). As a result of these investments, the PNACC and the CAS were approved in 2006 and 2016 respectively (Losada et al., 2019). This has opened a new period for investments, in such a 
way that specific adaptation measures began to be funded along the Spanish coast. In what follows, these initial investments are discussed.

Nonetheless, results presented in this study must be interpreted with caution and a number of limitations should be borne in mind. On the one hand, methodology limitations related to the lack of previous studies hamper further elaborations on previous findings. To our knowledge, this work is the first assessment on coastal adaptation investments in Spain at this early stage of implementation. Also, the absence of an official database reflecting all investments in coastal adaptation to climate change, drives us to compile these data from different official sources of information. In this sense, when information on given implemented measures exists we are sure that they took place. But, the non-presence of such information does not necessarily imply that it does not exist. However, due to the obligations of the Administration to officially report annual investments, we assume possible deviations to be small enough. Thus, our findings can be considered reliable and valid in the sense they have been obtained from reliable sources although, formally speaking, they would represent the minimum investment made on coastal adaptation to climate change.

\subsection{Is so-called adaptation really adaptation?}

Nature-based related measures have been mostly funded under the LIFE program, whereas the PIMA Adapta program has shown a larger focus on classical coastal engineering actions (unless sediment-based measures are considered as nature-based ones). The bias of LIFE projects to this type of measure is owing to the environmental protection orientation of the program. On the contrary, although the PIMA Adapta also considers this type of measure, this early-stage funding has been mainly concentrated in classical coastal engineering measures, which are used most often to tackle current coastal problems. As coastal management in Spain is mainly oriented for supporting recreation and protection functions and most of the investments are in urban coastal zones, these approaches are often seen to be the most costeffective measures. Gibbs (2016) also found that in terms of budget allocation, large-scale coastal protection infrastructure is typically government funded. Thus, one question left open by our analysis whether the funded projects have really been designed as an adaptation measure to climate change, or simply as short-term protection measures for solving current problems. 
475 Funded measures based on beach nourishment have been generally designed to tackle current

476 problems, providing continuity to previous works undertaken by the DGSCM where the 477 official objectives were shoreline stabilization and coastal protection. A typical example is the nourishment of the Benifali beach (Castellón, Valencia region) in 2017, an area that has been identified as a coastal hotspot for the impact of storms (CEDEX, 2015). The budget allocated

480

481

482

483

484

485

486

487

488

489

490

491

492

493

494

495

496

497

498

499

500

501

502

503

504

505

506

507 to PIMA Adapta was approximately $1 \mathrm{M} €$, which is approximately $27 \%$ of all of the investments in the Valencia region within the programme. The planned and executed works were designed to recover the beach functionality under current climatic conditions, and they did not account for the potential excess of erosion owing to sea level rise. Thus, although the measure can be considered as effective in recovering the beach, it cannot formally be considered as an adaptation to climate change. In other words, even without climate change, this measure had to be enacted. This can be extended to nearly all nourishment operations funded until present under PIMA Adapta.

One of the few nature-based measures funded under PIMA Adapta is dune building (and vegetating). An example of this is an artificial dune in the Tordera delta coast (Barcelona, Catalonia region) in 2016. This is a coastal hotspot subject to large erosion rates and susceptible to inundation during storm impacts (Jiménez et al., 2017), and is classified as a priority area within the Maresme Strategic Plan (CEDEX, 2014). The budget funded through PIMA Adapta was $0.15 \mathrm{M} €$, and it was the only physical measure funded through the programme in the Barcelona province. The dune was built during the first part of 2016 and, owing to the impact of storms on January/February 2017, it was destroyed at its northern part, where the beach was narrowest. The dune was essentially designed to prevent inundation of the hinterland during the incidence of storms and, owing to local conditions, it will hardly survive unless a minimum beach width is maintained in front of the dune. In spite of the fact that sediment eroded from the dune will contribute to the beach sediment budget, its mobilization at a very short-term scale hardly permits an assumption that it plays a quantifiable role in long-term coastal adaptation to sea level rise if no continuous maintenance is performed.

These examples of physical adaptation measures funded under PIMA Adapta have the common characteristic of being executed in areas experiencing problems under current climatic conditions, whereas the DGSCM actively invests in coastal protection. In fact, most of these actions have not been executed in an isolated manner, but they were a part of other concurrent protection works at such locations. Thus, although formally they were contributing 
to adapting the coast to climate change by improving its current state, the reality is that they had to be executed, even absent climate change. In other words, they were officially labelled as an adaptation measure (funded under PIMA Adapta), but they were mostly designed to solve current problems.

When these measures are considered in a long-term perspective (e.g. Hinkel et al., 2013), such as that associated with climate change adaptation, additional elements have to be considered. Thus, to enable nourishment as an effective long-term adaptation option, the existence of strategic sediment reservoirs (Marchand et al., 2011) to obtain the required present and future volumes is needed (e.g. Jiménez and Sanchez-Arcilla, 2019). Moreover, the design and execution are also key elements to be considered, i.e. continuous versus massive nourishments. An example of this is the Sand Motor project in the Netherlands, where approximately $21 \mathrm{M}$ of $\mathrm{m}^{3}$ of sand was supplied to the coast during a period of six months to counteract coastal erosion during a period of approximately 20 years (see details in Stive et al., 2013). According to the corresponding study, this would be more efficient, economical, and environmentally friendly in the long-term than traditional beach nourishments. By depositing a large amount of sand in a single operation, short-term replenishment would be unnecessary, thus avoiding repeated disruptions of the seabed, as well as decreasing unit dredging costs and taking advantage of financing opportunities (e.g. Stronkhorst et al., 2018).

This is also applicable to implementing hard measures, where functional designs under current conditions are not necessarily valid for future ones (e.g. Arns et al., 2017). A clear example of redesigning for future conditions is the Thames Barrier and its associated defences, which need to be upgraded to maintain the same level of protection. Despite being initially designed to resist flooding from storm surges, the Thames Estuary 2100 project proposed a strategy based on different adaptation pathways, depending on the rate of sea level rise (Environment Agency, 2009). Hall et al. (2019) suggest that the most cost-effective and robust adaptation pathway involves moving the Thames Barrier $17 \mathrm{~km}$ towards the sea if the mean sea level rises $2 \mathrm{~m}$ above the present level.

An example of a nature-based solution is the recovery of the ecological functionality of the coastal lagoon system of La Pletera (Girona, Catalonia, Mediterranean). This is an action funded through the LIFE programme (supplementary material, Table S1) and aiming to restore the integrity of a coastal lagoon system that was altered by abandoned infrastructure, by deconstructing built-up areas and restoring previous wetlands and their ecological 
functioning. The total investment was $2.5 \mathrm{M} €$, from which $75 \%$ was funded by the EU.

541 Different local stakeholders, led and coordinated by the Torroella de Montgrí municipality, supplied the rest of the investment. The origin of the project is a former study launched and funded by the DGSCM in 2007 to recover the ecological functionality of the area. They also modified the land planning to incorporate a previously urban-delineated zone to the public domain. The project has been fully executed and, in addition to the physical measures, it included a concerted communication, education and awareness-raising strategy. Although the objective is essentially based on ecological restoration, the adopted approach, which enhances the accommodation space in the area, can be easily included in any long-term adaptation scheme to climate change.

In this context, it has to be considered that recovering coastal ecosystem functionality, together with the generation of space is the basis of the development of ecosystem-based solutions for coping with global change (e.g. Temmerman et al., 2013). Until now, the implemented measures have only been placed in uninhabited areas, which certainly avoid social conflicts. However, when using as an adaptation measure to reduce future risks, this measure would imply affecting the local population and as such, it may have social implications of different degree depending on each case (Hino et al., 2017). In this context, the Spanish experience in redefining coastal setbacks so as to free occupied space in the coastal zone to apply to the Spanish Coastal Act is quite disappointing. In most of the cases, it becomes a very long administrative process, in which the affected population uses all possible judicial resources to avoid being relocated. In practice, this implies that in addition to space, time is one of the most important resources for implementing adaptation measures based on coastal retreat (Jiménez, 2019). Thus, if this option is going to be considered, it should be recommended to start the usual long administrative process and the negotiating process with the affected population as soon as possible. This also illustrates that social and institutional measures are useful and needed, not only at the early stages, but also throughout the entire adaptation process. However, their weight in the allocation of adaptation expenditures has to decrease progressively in benefit to the other types of structural-physical initiatives.

\subsection{What drives the spatial distribution of adaptation investments?}

According to the gathered data, the regions with highest current investments in adaptation are located along the Mediterranean coast (Andalusia, Catalonia and Valencia). These regions 
present some common features such as relatively long coastlines, high coastal GDP, and high coastal vulnerability. They are among the most visited regions by tourists and, considering the dominant role of sun and sand tourism (Aguiló et al., 2005), beaches are one of the main resources for economic development (Rigall-i-Torrent et al., 2011). These characteristics seem to indicate some rationality regarding investments, i.e. more vulnerable and/or economically important coastal regions can concentrate investments to progress towards better adaptations to climate change. In any case, it has to be considered that a significant part of the accounted investments are from LIFE funding (Figure 3), and to access them, regional stakeholders must participate in a competitive process which requires an active role. These regions caught more than $80 \%$ of the accounted LIFE funds, with Andalusia being the most successful region.

At the other end of the spectrum, two of the regions with the longest coastlines, the Spanish archipelagos of the Canary and Balearic Islands, are among the areas with the lowest current investments in adaptation. These types of insular territories are, however, also especially vulnerable to climate change (e.g. Mimura et al., 2007). Moreover, landscape transformation, associated with the dominant role of the tourism industry, has further increased the vulnerability of those islands (e.g. Pérez-Chacón et al., 2019; Roig-Munar et al., 2019). A possible explanation for such apparent underfunding could be associated to the fact that most of the existing beaches in these territories do not present significant problems of stability, and erosion is one of the major drivers in DGSCM investments in coastal protection. However, current problems related to landscape transformation and urban development are beyond the DGSCM competences, and although they can interact with climate change-induced problems, they are apparently not perceived as such. In any case, this apparent underfunding should be corrected, so as to account for territorial specificities in the near future.

One of the key elements in properly distributing investments in coastal adaptation to climate change is the existence of specific adaptation plans downscaled at the regional level, where local impacts, needs and measures are clearly defined. Once this is available for all coastal regions, solid criteria for funding distribution could be established. Without this, current investments are usually distributed using criteria based on current protection needs and, some generic elements, such as coastline length. In some way, this replicates the results obtained by Policy Research Corporation (2009a) when analysing coastal protection expenditures in the EU, which found that a small group of countries concentrated most of the investments (Spain was one of them). Countries more advanced in coastal protection and climate adaptation are in general those that are most affected by coastal hazards, and that have experienced severe 
weather events in the past. This can be observed specially in the North Sea countries concerned with flood risk, with the UK and the Netherlands as forerunners. The main difference is that, at European level, each country decides how much is invested in adaptation, whereas, at the national level, the government decides how the overall budget should be distributed. As previously mentioned, the active involvement of coastal regions in LIFE projects can attract additional and significant investments and, for the short period analysed, they have played a relevant role in determining the final expenditures in adaptation.

Considering that the current beach management in Spain is oriented towards recreational uses owing to their importance to the local economy, mobilising private finance would pump resources into coastal adaptation and protection investments. Future efforts on coastal adaptation should focus on grant financing and aligning public stakeholder and private investor interests in coastal adaptation projects, to overcome prevailing barriers and to help close the coastal adaptation-financing gap (Bisaro and Hinkel, 2018). In fact, coastal adaptation is often attractive from a purely economic perspective for soft and hard measures to maintain benefits from tourism (Hinkel et al., 2013), and require efficient coastal adaptation measures to maintain future beach widths to properly support tourist demand (e.g. López-Dóriga et al., 2019). However, they could also generate indirect revenues, as the associated tourism activities could be taxed (Kok et al., 2017). Therefore, delineating tax rates to account for unequal benefits of public funds could facilitate local investments in coastal adaptation (Mullin et al., 2019). Consequently, promoting public-private partnership with powerful (economic) stakeholders, for example, the tourism industry, can enhance coastal adaptation, as insufficient investments during earlier stages in changing conditions may lead to an increase in future expenditures.

\subsection{Coastal adaptation to climate change vs regular protection investments}

Expenditures in coastal protection in Spain at the beginning of 2000s (2000-2008) were among the five highest in Europe, with an average annual expenditure of approximately $52 \mathrm{M}$ $€ /$ year (Policy Research Corporation, 2009b), with values even higher during the 1990s, up to $82 \mathrm{M} € /$ year (Barragán, 2004). However, the national coastal budget significantly decreased after 2009, coinciding with the peak of the recent economic crisis (Figure 6). Therefore, the analysed period can be characterised by a relatively low investment in regular protection and 
adaptation to climate change measures as, even adding both together, the annual investment would not reach the values before the economic crisis.

During the last decade, and specifically from 2014 to 2018, the Spanish coastline has experienced significant damage associated with the impact of storms, in such a way that specific recovery programmes (Plan Litoral) were required (Figure 6). The spatial distribution of these investments depended on where storm occurred, and hence was concentrated in neighbouring regions during a given year (Figure 7). As an example, the 2014 programme was fully dedicated to the Cantabric/Atlantic coastal regions, to compensate for damages induced by the storm season of 2013/2014, which also significantly damaged the coast of southeast England and France (e.g. Masselink et al., 2016). In contrast, the 2017 programme was dedicated to the Mediterranean coastal regions.

\section{$<$ Figure $7>$}

These damages, and consequently the budgets required for recovery, are expected to increase with time. Jiménez et al. (2012) detected an increase in coastal damage along the Catalan coastline in recent decades. They found that this increase was not related to any trend in storminess, but rather was associated with a progressive decrease in the protection capacity of eroding beaches. Thus, any scenario of sea level rise and subsequent induced shoreline retreat will even further decrease the protection provided by beaches to storm impacts (e.g. Jiménez et al., 2017). All of these characterises the Spanish coastline as vulnerable to storm impacts, with expected increasing budget demands for recovery measures owing to the effects of sea level rise. Thus, the lack of adequate investment for maintaining beaches at optimum configurations to provide protection against the impacts of storms will tend to increase the needs and importance of this additional budget. In other words, if less money is currently invested, future expenditures will significantly increase above expected levels.

On the whole, coastal protection and climate change adaptation activities are highly interlinked. In Spain, it is difficult to indicate which part of the investment is solely made in relation to climate change adaptation. Thus, adaptation measures are undertaken together with regular coastal protection activities. In fact, some management policies and procedures for coastal natural hazards are often seen as able to be managed without having an activated coastal adaptation plan in place (Gibbs, 2016). However, there is no existing framework 
designed to systematically assess the adaptation progress at the national level (UNEP, 2017). Tracking how adaptation is taking place allows researchers to document best practices, to facilitate early adoption of efficient adaptation measures, and to assess progress of adaptation efforts over time and space (Berrang-Ford et al., 2019). In spite of being costly, investing now in coastal adaptation will bring greater benefits in the future, and a monitoring plan of adaptation will enable us to learn lessons regarding what works, where and why.

\section{Conclusions}

Understanding the costs of adaptation, how adaptation has been and is currently being funded, and what funding mechanisms have been used, and following the criteria to distribute the investments will help in decision-making for the long-term planning and implementation of adaptation measures. Within this context, this work analysed how coastal adaptation is being financed in the early stages of implementation of the CAS in Spain.

According to the strategy, financing options will be specified once measures have been defined and prioritised. At the current stage, and in the absence of a detailed implementation plan, coastal adaptation has been financed through national (PIMA Adapta) and EU funds (LIFE projects). Measures financed through PIMA Adapta are mainly based on traditional coastal engineering actions, and they are implemented in areas experiencing problems under current climatic conditions. Thus, although they would contribute to adaptation by improving the current state of the coast, they would need to be implemented even under a non-changing climate. This makes the identification of the part of the investment that is solely related to climate change adaptation a difficult task. Consequently, it may affect tracking the adoption and implementation of adaptation in reality. Adaptation measures using LIFE-funding are more oriented towards nature/ecosystem-related actions, owing to the conditions imposed by this funding programme. In most of the cases, although they were designed as environmental/ecological restoration actions, they also play out as adaptation measures.

Solving current coastal problems under the guise of adaptation is a two-sided concept. On the positive side, it allows to improve the current coastal status, which will enhance adaptation to future changes. However, unless additional climate-induced effects are accounted for the design of measures, these investments will be insufficient for coping with future changes. A 
simple way to assess whether future conditions are considered in the design of coastal

700

701

702

703

704

705

706

707

708

709

710

711

712

713

714

715

716

717

718

719

720

721

722 measures is by analysing the time evolution of investments in coastal protection. In Spain, with large vulnerable areas under current conditions, anything that it is not an increase in total expenditure with respect to previous years would indicate an underinvestment in coastal adaptation.

All coastal adaptation actions analysed here have been financed through public funds. This is a legacy of the traditional coastal protection policy, which allocates to the State the competence, the right, and the obligation to protect our coasts. However, coastal adaptation can be tackled through different alternatives, with various consequences for the stakeholders. This can be an opportunity to access private financing for adaptation by selecting alternatives that, while meeting official sustainability targets, also permit meeting the specific needs of stakeholders. In countries with an important coastal tourism industry and/or a large part of the GDP associated with the tourism sector (for example, many Mediterranean countries), contributing to financing coastal adaptation could be considered as an additional cost in this sector.

Although the adaptation resource considered here is money, time is the most evident declining resource. Although we are at the beginning of the implementation of adaptation measures, these need to be undertaken and implemented with respect to time. Delays and/or actions not taken properly and timely during the initial stages could result in higher costs arising in the future. Finally, it has to be stressed that the misuse of the concept of adaptation measure will tend to the society to be overconfident about adopted actions whereas they are not really progressing to real adaptation. To overcome this risk, it is necessary to have a clear roadmap for implementing adaptation measures together a proper financing structure. 
724

725

Table 1. Key numbers for Spain's coastal regions (data from National Statistics Institute (INE), 2015). Coastal GDP and population only consider information from coastal provinces within each region (dark grey areas in Figure 1).

Table 2. Examples of Environment Promotion Plan for Climate Change Adaptation (PIMA Adapta) coastal actions in different locations in Spain.

\section{Figure captions:}

Figure 1. Coastal regions in Spain (see names in Table 1).

Figure 2. Methodological framework to analyse progress in implementing coastal adaptation measures at National scale.

Figure 3. Percentage of expenditures per typology of adaptation measures in Spain.

Figure 4. Investment in coastal adaptation to climate change in Spanish coastal regions. Note: $12.8 \mathrm{M} €$ are destined for general measures without specific territorial assignment.

Figure 5. Investment in coastal adaptation per region vs. regional indicators. (A: coastline length; B: GDP of coastal provinces within the region; C: average coastal vulnerability index (CVI)). (*: indicate excluded values to obtain alternative relationship -blue dashed line-).

Figure 6. Current expenditures by the General Directorate for Sustainability of the Coast and the Sea (DGSCM) in coastal protection measures. Note: this annual expenditure is referred to as "regular" budget).

Figure 7. Regional distribution of storm recovery programmes (Plan Litoral). (Location of regions can be seen in Figure 1).

\section{Appendix A. Supplementary data}

Table S1. LIFE projects included in this work.

Table S2. Classification of adaptation options categories (MAGRAMA, 2016). (P: protection, A: accommodation, R: retreat; O: others).

Table S3. Reclassification of categories of adaptation options (see codes in Table S2).

Table S4. DGSCM objectives and their relation with adaptation actions included in the CAS (see codes in Table S2). 
752

753

754

755

756

757

758

759

760

761

762

763

764

765

766

767

768

769

770

771

772

773

774

775

776

777

778

779

780

781

782

783

This work was supported by the Spanish Ministry of Economy and Competitiveness (MINECO/AEI/FEDER, UE) in the framework of the M-CostAdapt research project (CTM2017-83655-C2-1-R). The first author was supported by a PhD grant from the Spanish

Ministry of Economy and Competitiveness. We also thank the support of the Secretaria d'Universitats i Recerca del Departament d'Economia I Coneixement de la Generalitat de Catalunya (2017SGR773).

\section{References}

Aguiló, E., Alegre, J., Sard, M. 2005. The persistence of the sun and sand tourism model. Tourism Management, 26(2), 219-231. https://doi.org/10.1016/j.tourman.2003.11.004.

Araos, M., Berrang-Ford, L., Ford, J. D., Austin, S. E., Biesbroek, R., Lesnikowski, A. 2016. Climate change adaptation planning in large cities: A systematic global assessment. $\begin{array}{llll}\text { Environmental Science } \quad \& \quad \text { Policy, } & \text { 375-382. }\end{array}$ https://doi.org/10.1016/j.envsci.2016.06.009.

Arns, A., Dangendorf, S., Jensen, J., Talke, S., Bender, J., Pattiaratchi, C. 2017. Sea-level rise induced amplification of coastal protection design heights. Scientific Reports, 7, 40171. https://doi.org/10.1038/srep40171.

Barragán, J.M. 2004. Las áreas litorales de España. Del análisis geográfico a la gestión integrada. 214p., Ariel, Barcelona, España. ISBN: 8477868298. 214p., Ariel, Barcelona, España. ISBN: 8477868298.

Beatley, T., 2012. Planning for Coastal Resilience: Best Practices for Calamitous Times. Island Press, Washington, DC.

Berrang-Ford, L., Biesbroek, R., Ford, J. D., Lesnikowski, A., Tanabe, A., Wang, F. M., Chen, C., Hsu, A., Hellmann, J.J., Pringle, P., Grecequet, M., Amado, J.C., Huq, S., lwasa, S., Heymann, S.J. 2019. Tracking global climate change adaptation among governments. Nature Climate Change, 9, 440-449. https://doi.org/10.1038/s41558-019-0490-0.

Berrang-Ford, L., Ford, J.D., Paterson, J. 2011. Are we adapting to climate change? Global Environmental Change, 21(1), 25-33. https://doi.org/10.1016/j.gloenvcha.2010.09.012.

Biesbroek, G.R., Swart, R.J., Carter, T.R., Cowan, C., Henrichs, T., Mela, H., Morecroft, M.D., Rey, D. 2010. Europe adapts to climate change: Comparing National Adaptation 
Strategies. Global Environmental Change, 20(3), 440-450. https://doi.org/10.1016/j.gloenvcha.2010.03.005.

Bisaro, A., Hinkel, J. 2018. Mobilizing private finance for coastal adaptation: A literature review. Wiley Interdisciplinary Reviews: Climate Change, 9(3), e514, https://doi.org/10.1002/wcc.514.

CEDEX. 2014. Estudios de dinámica litoral, defensa y propuestas de mejora en las playas con problemas erosivos, considerando los efectos del cambio climático. Estrategia de actuación en el Maresme. Informe final. Centro de Estudios y Experimentación de Obras Públicas. Ministerio de Agricultura, Alimentación y Medio Ambiente, Madrid.

CEDEX. 2015. Estudios de dinámica litoral, defensa y propuestas de mejora en las playas con problemas erosivos, considerando los efectos del cambio climático. Estrategia de actuación del tramo de costa comprendido entre el puerto de Castellón y el Puerto de Sagunto (Castellón sur). Informe final. Centro de Estudios y Experimentación de Obras Públicas. Ministerio de Agricultura, Alimentación y Medio Ambiente, Madrid.

Del Río, L., Gracia, F.J., Benavente, J. 2013. Shoreline change patterns in sandy coasts. A case study in SW Spain. Geomorphology, 196, 252-266. https://doi.org/10.1016/j.geomorph.2012.07.027.

Del Río, L., Plomaritis, T.A., Benavente, J., Valladares, M., Ribera, P. 2012. Establishing storm thresholds for the Spanish Gulf of Cádiz coast. Geomorphology, 143, 13-23. https://doi.org/10.1016/j.geomorph.2011.04.048.

DGSCM. 2016. Estrategia de adaptación al cambio climático de la costa española. Dirección General de Sostenibilidad de la Costa y El Mar. Ministerio de Agricultura y Pesca, Alimentación y Medioambiente, Madrid.

EEA, 2008. Impacts of Europe's changing climate -2008 indicador-based assessment. Joint EEA-JRC_WHO Report. European Environment Agency, Copenhagen. https://www.eea.europa.eu/publications/eea_report_2008_4 (accessed 01/10/19).

Eisenack, K., Moser, S.C., Hoffmann, E., Klein, R.J.T., Oberlack, C., Pechan, A., Rotter, M., Termeer, C.J.A.M. 2014. Explaining and overcoming barriers to climate change adaptation. Nature Climate Change, 4, 867-872. https://doi.org/10.1038/nclimate2350.

Enríquez, A.R., Marcos, M., Álvarez-Ellacuría, A., Orfila, A., Gomis, D. 2017. Changes in beach shoreline due to sea level rise and waves under climate change scenarios: application to the Balearic Islands (western Mediterranean). Natural Hazards and Earth System Sciences, 17, 1075-1089. https://doi.org/10.5194/nhess-17-1075-2017. 
Environment Agency, 2009. Thames Estuary 2100: Managing flood risk through London and the Thames estuary, London.

European Commision, 2013. The EU Strategy on adaptation to climate change. European Commision, Brussels, Belgium. https://ec.europa.eu/clima/policies/adaptation/what_en (accessed 01/10/19).

European Commission. 2018. Evaluation of the EU's Strategy on Adaptation to Climate Change. Adaptation preparedness scoreboard: Draft country fiche for Spain. https://ec.europa.eu/clima/sites/clima/files/consultations/docs/0035/es_en.pdf (accessed 03/04/2019)

Ford, J.D., Berrang-Ford, L., Paterson, J. 2011. A systematic review of observed climate change adaptation in developed nations. Climatic Change, 106, 327-336. https://doi.org/10.1007/s10584-011-0045-5.

Gibbs, M.T. 2016. Why is coastal retreat so hard to implement? Understanding the political risk of coastal adaptation pathways. Ocean \& Coastal Management, 130, 107-114. https://doi.org/10.1016/j.ocecoaman.2016.06.002.

Gibbs, M. T. 2019. Consistency in coastal climate adaption planning in Australia and the importance of understanding local political barriers to implementation. Ocean \& Coastal Management, 173, 131-138. https://doi.org/10.1016/j.ocecoaman.2019.03.006.

Gornitz, V., Kanciruk, P. 1989. Assessment of global coastal hazards from sea level rise. Coastal Zone ' 89 . In: Proceedings of sixth symposium on coastal and ocean management, ASCE, Charleston, South Carolina, pp 1345-1359.

Haasnoot, M., Brown, S., Scussolini, P., Jiménez, J.A., Vafeidis, A.T., Nicholls, R.J. 2019. Generic adaptation pathways for coastal archetypes under uncertain sea-level rise. Environmental Research Communications, (in press). https://doi.org/10.1088/2515$7620 / \mathrm{ab} 1871$.

Hall, J. W., Harvey, H., Manning, L. J. 2019. Adaptation thresholds and pathways for tidal flood risk management in London. Climate Risk Management, 24, 42-58. https://doi.org/10.1016/j.crm.2019.04.001.

Hinkel, J., Aerts, J.C., Brown, S., Jiménez, J.A., Lincke, D., Nicholls, R.J., Scussolini, P., Sánchez-Arcilla, A., Vafeidis, A., Appeaning Addo, K. 2018. The ability of societies to adapt to $21 \mathrm{st}$ century sea-level rise. Nature Climate Change, 8, 570-578. https://doi.org/10.1038/s41558-018-0176-z.

Hinkel, J., Lincke, D., Vafeidis, A. T., Perrette, M., Nicholls, R. J., Tol, R. S., Marzeion, B., Fettweis, X., Ionescu, C., Levermann, A. 2014. Coastal flood damage and adaptation costs 
under 21st century sea-level rise. Proceedings of the National Academy of Sciences, 111(9), 3292-3297. https://doi.org/10.1073/pnas.1222469111.

Hinkel, J., Nicholls, R. J., Tol, R. S., Wang, Z. B., Hamilton, J. M., Boot, G., Vafeidis, A.T., McFadden, L., Ganopolski, J.A., Klein, R.J. 2013. A global analysis of erosion of sandy beaches and sea-level rise: An application of DIVA. Global and Planetary change, 111, 150-158. https://doi.org/10.1016/j.gloplacha.2013.09.002.

Hino, M., Field, C.B., Mach, K.J. 2017. Managed retreat as a response to natural hazard risk. Nature Climate Change, 7, 364. https://doi.org/10.1038/nclimate3252.

Jiménez, J.A. 2019. Barreras a la adaptación costera a la subida del nivel del mar. XV Jornadas Españolas de Ingeniería de Costas y Puertos. Torremolinos, Málaga, Spain.

Jiménez, J.A., Sánchez-Arcilla, A. 2019. Adaptation to SLR in Mediterranean urban coasts. The Barcelona case. Coastal Sediments 2019, St Pete, USA World Scientific Press, 11271141.

Jiménez, J.A., Sancho, A., Bosom, E., Valdemoro, H.I., Guillen, J. 2012. Storm-induced damages along the Catalan coast (NW Mediterranean) during the period 1958-2008. Geomorphology 143-144, 24-33. https://doi.org/10.1016/j.geomorph.2011.07.034.

Jiménez, J.A., Valdemoro H.I. 2019. Shoreline evolution and management implications in beaches along the Catalan coast. In: Morales, J.A. (eds), The Spanish coastal systems. Dynamic processes, sediments and management. Springer, 745-764. https://doi.org/10.1007/978-3-319-93169-2_32.

Jiménez, J.A., Valdemoro, H.I., Bosom, E., Sánchez-Arcilla, A., Nicholls, R.J. 2017. Impacts of sea-level rise-induced erosion on the Catalan coast. Regional Environmental Change, 17, 593-603. https://doi.org/10.1007/s10113-016-1052-X.

Khan, M.R., Roberts, J.T. 2013. Adaptation and international climate policy. Wiley Interdisciplinary Reviews: Climate Change, 4(3), 171-189. https://doi.org/10.1002/wcc.212.

Kok, S., de Bel, M., Bisaro, A., Hinkel, J., Bouwer, L. M. 2017. Assessing nature-based flood defence as a win-win strategy to leverage public funding for adaptation to coastal flood risk. Paper presented at GREEN-WIN Global Adaptation Finance Stakeholder Workshop, Delft, Netherlands.

Lesnikowski, A. C., Ford, J.D., Berrang-Ford, L., Barrera, M., Heymann, J. 2015. How are we adapting to climate change? A global assessment. Mitigation and Adaptation Strategies for Global Change, 20(2), pp. 277-293. https://doi.org/10.1007/s11027-013-9491-x. 
Lesnikowski, A. C., Ford, J.D., Biesbroek, R., Berrang-Ford, L., Heymann, S.J. 2016. National-level progress on adaptation. Nature Climate Change, 6(3), 261-264. https://doi.org/10.1038/nclimate2863.

López-Doriga, U., Jiménez, J.A., Valdemoro H.I., Nicholls, R.J. 2019. Impact of sea-level rise on the tourist-carrying capacity of Catalan beaches. Ocean \& Coastal Management, 170, 40-50. https://doi.org/10.1016/j.ocecoaman.2018.12.028.

López-Royo, M., Ranashinge, R., Jiménez, J.A. 2016. A rapid, low cost approach for coastal vulnerability assessment at a national scale. Journal of Coastal Research, 32(4), 932-945. https://doi.org/10.2112/JCOASTRES-D-14-00217.1.

Losada, I., Izaguirre, C., Diaz, P. 2014. Cambio climático en la costa española. Oficina Española de Cambio Climático, Ministerio de Agricultura, Alimentación y Medio Ambiente. Madrid, 133 pp.

Losada, I. J., Toimil, A., Muñoz, A., Garcia-Fletcher, A. P., Diaz-Simal, P. 2019. A planning strategy for the adaptation of coastal areas to climate change: The Spanish case. Ocean \& Coastal Management, 104983. https://doi.org/10.1016/j.ocecoaman.2019.104983.

Marchand, M., Sanchez-Arcilla, A., Ferreira, M., Gault, J., Jiménez, J. A., Markovic, M., Mulder, J., van Rijn, L., Stanica, A., Sulisz, W., Sutherland, J. 2011. Concepts and science for coastal erosion management-An introduction to the Conscience framework. Ocean \& Coastal Management, 54, 859-866.

Martínez-Graña, A., Gómez, D., Santos-Francés, F., Bardají, T., Goy, J.L., Zazo, C. 2018. Analysis of Flood Risk Due to Sea Level Rise in the Menor Sea (Murcia, Spain). Sustainability, 10(3), 780. https://doi.org/10.3390/su10030780.

Masselink, G., Scott, T., Poate, T., Russell, P., Davidson, M., Conley, D. 2016. The extreme 2013/2014 winter storms: Hydrodynamic forcing and coastal response along the southwest coast of England. Earth Surface Processes and Landforms, 41(3), 378-391. https://doi.org/10.1002/esp.3836.

Mimura, N., Nurse, L., McLean, R.F., Agard, J., Briguglio, L., Lefale, P., Payet, R., Sem, G. 2007. Small islands. Climate Change 2007: Impacts, Adaptation and Vulnerability. Contribution of Working Group II to the IPPC AR4 Cambridge University Press, 687-716. Mimura, N., Pulwarty, R.S., Duc, D.M., Elshinnawy, I., Redsteer, M.H., Huang, H.Q., Nkem, J.N., Rodríguez, R.A.S., Moss, R., Vergara, W., Darby, L.S., Kato, S. 2014. Adaptation planning and implementation. In: Field, C.B., Barros, V.R., Dokken, D.J. et al (eds.), Climate Change 2014 Impacts, Adaptation and Vulnerability: Part A: Global and Sectoral Aspects. Contribution of Working Group II to the Fifth Assessment Report of the 
Intergovernmental Panel on Climate Change, Cambridge University Press, pp. 869-898.

Moser, S.C., Ekstrom J.A., Kim, J., Heitsch, S. 2018. Adaptation finance challenges: characteristic patterns facing California local governments and ways to overcome them. California's Fourth Climate Change Assessment. California Natural Resources Agency. Publication number: CCCA4-CNRA-2018-007.

Mullin, M., Smith, M. D., McNamara, D. E. 2019. Paying to save the beach: effects of local finance decisions on coastal management. Climatic Change, 152(2), 275-289. https://doi.org/10.1007/s10584-018-2191-5.

Nicholls, R.J., 2011. Planning for the impacts of sea level rise. Oceanography 24 (2), 144-157.

Nicholls, R.J., Hinkel, J., Lincke, D., van der Pol, T. 2019. Global Investment Costs for Coastal Defense through the 21st Century. The World Bank.

Nicholls, R.J., Wong, P.P., Burkett, V.R. , Codignotto, J.O. , Hay, J.E., McLean, R.F., Ragoonaden, S., Woodroffe, C.D. 2007. Coastal systems and low-lying areas. In: Parry, M.L., Canziani, O.F., Palutikof, J.P. et al. (Eds.), Climate Change 2007: Impacts, Adaptation and Vulnerability. Contribution of Working Group II to the Fourth Assessment Report of the Intergovernmental Panel on Climate Change, Cambridge University Press, Cambridge, 315-356.

Noble, I.R., S. Huq, Y.A. Anokhin, J. Carmin, D. Goudou, F.P. Lansigan, B. Osman-Elasha, Villamizar, A. 2014. Adaptation needs and options. In: Climate Change 2014: Impacts, Adaptation, and Vulnerability. Part A: Global and Sectoral Aspects. Contribution of Working Group II to the Fifth Assessment Report of the IPCC. Cambridge University Press, Cambridge.

OECC. 2006. Plan nacional de adaptación al cambio climático. Primer Programa de Trabajo 2006-2009. OECC. Secretaría de Estado de Medio Ambiente. Ministerio de Agricultura, Alimentación y Medio Ambiente. Madrid. https://www.miteco.gob.es/es/cambioclimatico/temas/impactos-vulnerabilidad-y-adaptacion/pna_v3 tcm7-12445_tcm3070393.pdf (accessed 03/04/2019).

OECC. 2009. Plan nacional de adaptación al cambio climático. Segundo programa de trabajo 2009-2013. OECC. Secretaría de Estado para el Cambio Climático. Ministerio de Medio Ambiente y Medio Rural y Marino. Madrid. (https://www.miteco.gob.es/es/cambioclimatico/temas/impactos-vulnerabilidad-y-adaptacion/2_prog_trabajo_tcm30-70398.pdf) (accessed 03/04/2019).

OECC. 2014. Plan nacional de adaptación al cambio climático. Tercer programa de trabajo 2014-2020. OECC. Secretaría de Estado de Medio Ambiente. Ministerio de Agricultura, 
Alimentación y Medio Ambiente. Madrid. (https://www.miteco.gob.es/es/cambioclimatico/temas/impactos-vulnerabilidad-y-adaptacion/3PT-PNACC-enero-2014 tcm3070397.pdf) (accessed 03/04/2019).

Orts, R. 2016. La costa Española y su protección. Ribagua 2.

Pearce, T. D., Rodríguez, E. H., Fawcett, D., Ford, J. D. 2018. How is Australia adapting to climate change based on a systematic review?. Sustainability, 10(9), 3280. https://doi.org/10.3390/su10093280.

Penning-Rowsell, E.C., Priest, S.J. 2015. Sharing the burden of increasing flood risk: who pays for flood insurance and flood risk management in the United Kingdom. Mitigation and adaptation strategies for global change 20, 991-1009. https://doi.org/10.1007/s11027014-9622-z.

Pérez-Chacón, E., Peña-Alonso, C., Santana-Cordero, A.M., Hernández-Calvento, L. 2019. The Integrated Coastal Zone Management in the Canary Islands. In: Morales, J.A. (ed), The Spanish coastal systems. Dynamic processes, sediments and management. Springer, 789-814. https://doi.org/10.1007/978-3-319-93169-2_34.

Policy Research Corporation (in Association with MRAG). 2009a. The Economics of Climate Change Adaptation in EU Coastal Areas. Final report. European Commission, Brussels, $153 \mathrm{pp}$ (https://climate-adapt.eea.europa.eu/metadata/publications/economics-of-climatechange-adaptation-eu-coasts) (accessed 03/04/2019).

Policy Research Corporation (in Association with MRAG). 2009b. The Economics of Climate Change Adaptation in EU Coastal Areas. Country overview and assessment. Spain. European Commission, Brussels, http://ec.europa.eu/maritimeaffairs/ documentation/studies/documents/spain_en.pdf (accessed 03/04/2019).

Rigall-i-Torrent, R., Fluvià, M., Ballester, R., Saló, A., Ariza, E., Espinet, J.M. 2011. The effects of beach characteristics and location with respect to hotel prices. Tourism Management, 32, 1150-1158. https://doi.org/10.1016/j.tourman.2010.10.005.

Rodríguez-Ramírez, A., Ruiz, F., Cáceres, L.M., Vidal, J.R., Pino, R., Muñoz, J.M. 2003. Analysis of the recent storm record in the southwestern Spanish coast: implications for littoral management. Science of the Total Environment, 303(3), 189-201. https://doi.org/10.1016/S0048-9697(02)00400-X.

Roig-Munar, F.X., Martín Prieto, J.A., Pintó, J., Rodríguez-Perea, A., Gelabert, B. 2019. Coastal Management in the Balearic Islands. In: Morales, J.A. (eds), The Spanish coastal systems. Dynamic processes, sediments and management. Springer, 765-787. 
Sanjaume, E., Pardo-Pascual, J.E. 2005. Erosion by human impact on the Valencian coastline (E of Spain). Journal of Coastal Research, 76-82.

Stive, M.J.F., de Schipper, A., Liijendijk, A.P., Aarninkhof, S.G.J., van Gelder-Maas, C., van Thiel de Vries, J.S.M., de Vries, S., Henríquez, M., Marx, S., Ranasinghe, R. 2013. A new alternative to saving our beaches from sea-level rise: The Sand Engine. Journal of Coastal Research, 29(5), 1001-1008. https://doi.org/10.2112/JCOASTRES-D-13-00070.1.

Storbjörk, S., Hedrén, J. 2011. Institutional capacity-building for targeting sea-level rise in the climate adaptation of Swedish coastal zone management. Lessons from Coastby. Ocean \& Coastal Management 54, 265-273. https://doi.org/10.1016/jocecoaman.2010.12.007.

Stronkhorst, J., Huisman, B., Giardino, A., Santinelli, G., Santos, F.D. 2018. Sand nourishment strategies to mitigate coastal erosion and sea level rise at the coasts of Holland (The Netherlands) and Aveiro (Portugal) in the 21st century. Ocean \& Coastal Management, 156, 266-276. https://doi.org/10.1016/jocecoaman.2017.11.017.

Temmerman, S., Meire, P., Bouma, T.J., Herman, P.M., Ysebaert, T., De Vriend, H.J. 2013. Ecosystem-based coastal defence in the face of global change. Nature, 504, 7478, 79. https://doi.org/10.1038/nature12859.

Toimil, A., Díaz-Simal, P., Losada, I.J., Camus, P. 2018. Estimating the risk of loss of beach recreation value under climate change. Tourism Management, 68, 387-400. https://doi.org/10.1016/j.tourman.2018.03.024.

UNEP, 2016. The Adaptation Finance Gap Report 2016. United Nations Environment Programme (UNEP). Nairobi, Kenya.

UNEP, 2017. The Adaptation Gap Report. Towards Global Assessment. United Nations Environment Programme (UNEP), Nairobi, Kenya.

Woodruff, S. C., Regan, P. 2019. Quality of national adaptation plans and opportunities for improvement. Mitigation and Adaptation Strategies for Global Change, 24(1), 53-71. https://doi.org/10.1007/s11027-018-9794-z. 
Table 1. Key numbers for Spain's coastal regions (data from National Statistics Institute (INE), 2015). Coastal GDP and population only consider information from coastal provinces within each region (dark grey areas in Figure 1).

\begin{tabular}{|c|c|c|c|}
\hline Region & $\begin{array}{c}\text { Coastal length } \\
(\mathbf{k m})\end{array}$ & $\begin{array}{c}\text { Coastal GDP } \\
\text { (millions } \boldsymbol{€})\end{array}$ & $\begin{array}{c}\text { Coastal } \\
\text { population } \\
\text { (inhabitants) }\end{array}$ \\
\hline Galicia (1) & 1,498 & 50.15 & $1,425,745$ \\
\hline Asturias (2) & 401 & 21.22 & $1,075,279$ \\
\hline Cantabria (3) & 284 & 12.20 & 566,678 \\
\hline Basque Country (4) & 246 & 55.00 & $1,829,822$ \\
\hline Catalonia (5) & 699 & 193.35 & $6,595,767$ \\
\hline Valencia (6) & 518 & 100.77 & $4,692,449$ \\
\hline Murcia (7) & 274 & 28.21 & $1,335,792$ \\
\hline Andalusia (8) & 945 & 85.05 & $4,591,231$ \\
\hline Balearic Islands (9) & 1,428 & 27.34 & 983,131 \\
\hline Canary Islands (10) & 1,583 & 40.92 & $1,968,280$ \\
\hline Ceuta (11) & 20 & 1.59 & 75,276 \\
\hline Melilla (12) & 9 & 1.46 & 65,488 \\
\hline
\end{tabular}


Table 2. Examples of Environment Promotion Plan for Climate Change Adaptation (PIMA Adapta) coastal actions in different locations in Spain.

\begin{tabular}{|c|c|c|c|c|}
\hline Measure & Location & $\begin{array}{c}\text { Link to climate change } \\
\text { adaptation }\end{array}$ & Year & Source \\
\hline $\begin{array}{c}\text { Environmental } \\
\text { recovery and beach } \\
\text { nourishment }\end{array}$ & Castellón (Valencia) & $\begin{array}{l}\text { Reduce coastal exposure } \\
\text { Stabilize shoreline }\end{array}$ & 2017 & $\frac{\text { MITECO }}{\underline{\text { website (1) }}}$ \\
\hline $\begin{array}{c}\text { Artificial dune } \\
\text { creation and } \\
\text { vegetation settlement }\end{array}$ & $\begin{array}{l}\text { Malgrat de Mar } \\
\text { (Catalonia) }\end{array}$ & $\begin{array}{l}\text { Reduce coastal exposure } \\
\text { Stabilize shoreline }\end{array}$ & 2016 & $\frac{\text { MITECO }}{\text { website (2) }}$ \\
\hline $\begin{array}{l}\text { Wetland restoration } \\
\text { and environmental } \\
\text { recovery }\end{array}$ & A Coruña (Galicia) & $\begin{array}{l}\text { Maintain coastal ecosystems in } \\
\text { good conditions } \\
\text { Promote Nature-based solutions } \\
\text { (NBS) }\end{array}$ & 2016 & $\frac{\text { MITECO }}{\text { website (3) }}$ \\
\hline $\begin{array}{l}\text { Sand management } \\
\text { (by-pass) }\end{array}$ & Almeria (Andalusia) & $\begin{array}{l}\text { Reduce coastal exposure } \\
\text { Stabilize shoreline }\end{array}$ & 2015 & $\begin{array}{r}\text { MITECO } \\
\text { website (4) }\end{array}$ \\
\hline $\begin{array}{l}\text { Slope stabilization and } \\
\text { coastal protection }\end{array}$ & $\begin{array}{l}\text { Several municipalities } \\
\text { in Asturias }\end{array}$ & Protect the coast & 2015 & $\frac{\text { MITECO }}{\text { website (5) }}$ \\
\hline $\begin{array}{l}\text { Artificial defences } \\
\text { (groynes and } \\
\text { breakwaters) }\end{array}$ & Almeria (Andalusia) & $\begin{array}{l}\text { Reduce coastal exposure } \\
\text { Stabilize shoreline }\end{array}$ & 2015 & $\frac{\text { MITECO }}{\text { website }(6)}$ \\
\hline $\begin{array}{l}\text { Groyne removal and } \\
\text { sand re-distribution }\end{array}$ & Cartagena (Murcia) & $\begin{array}{c}\text { Stabilize shoreline } \\
\text { Mitigate erosion problems }\end{array}$ & 2017 & $\frac{\text { MITECO }}{\text { website (7) }}$ \\
\hline
\end{tabular}




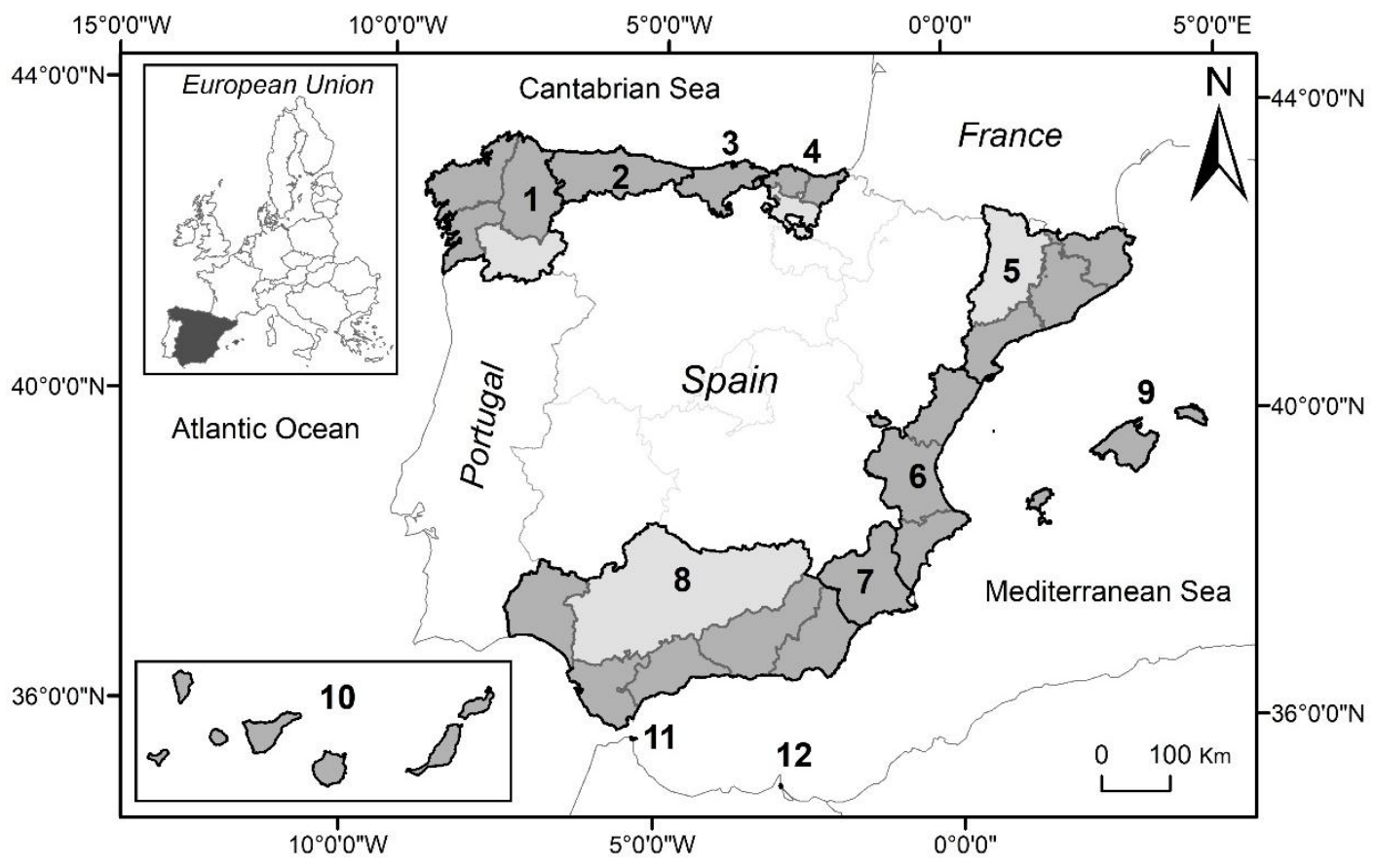

Figure 1. Coastal regions in Spain (see names in Table 1). 


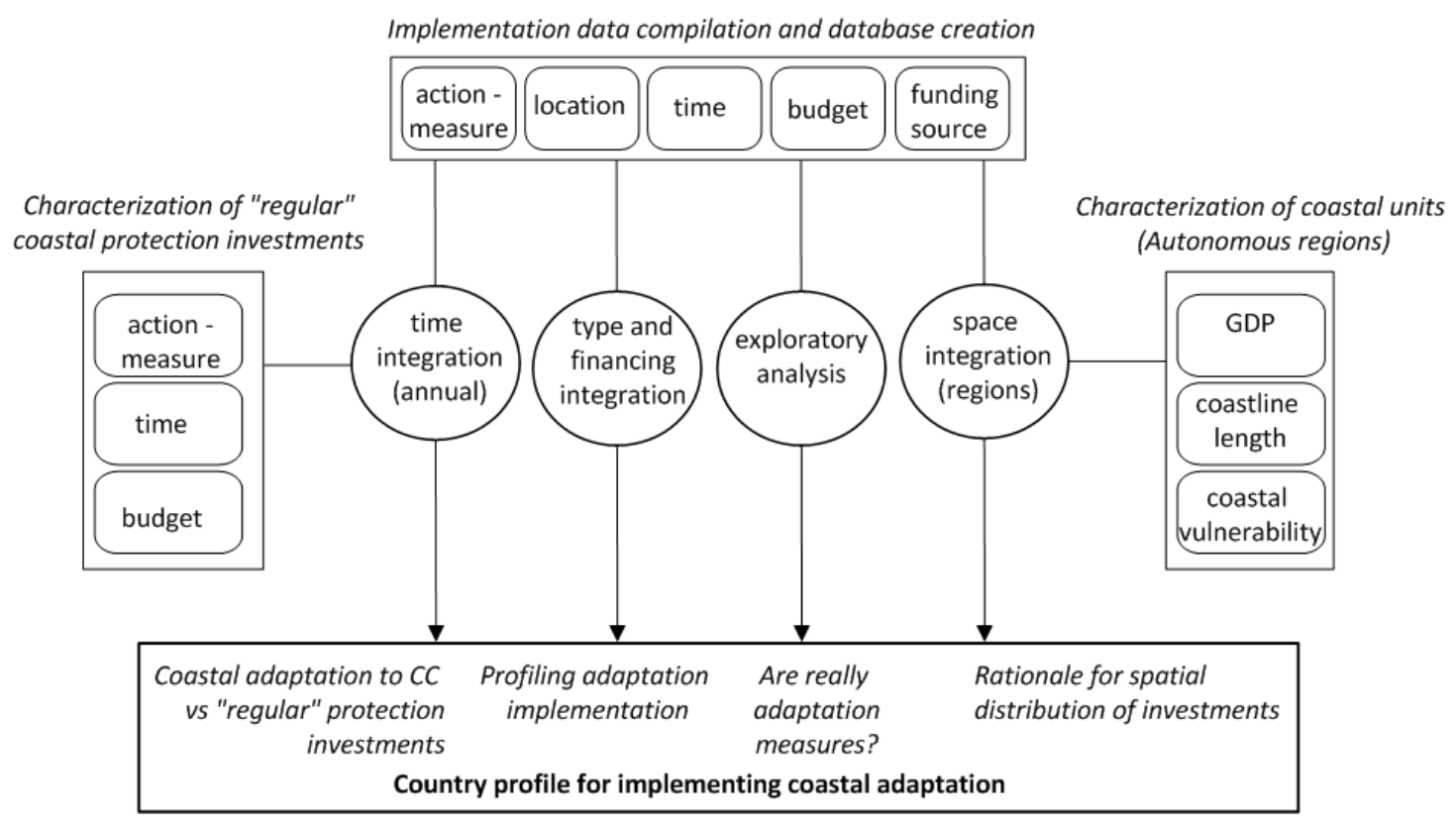

Figure 2. Methodological framework to analyse progress in implementing coastal adaptation measures at National scale. 


\section{Figure 3}

Click here to download Figure: Figure 3.doc

Soft defences
Hard defences
Nature-based solutions
Mixed
Training+awareness
Integration decision-making
process
Research
Evaluation ecosystem services
Protected areas
W/o specifying

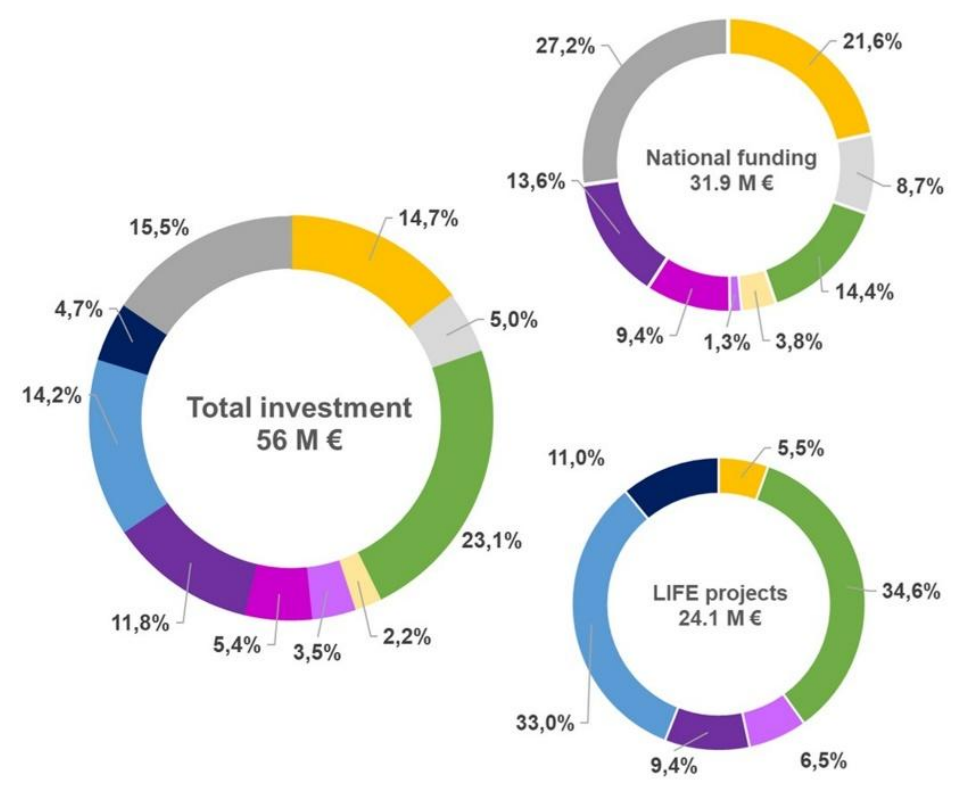

Figure 3. Percentage of expenditures per typology of adaptation measures in Spain. 


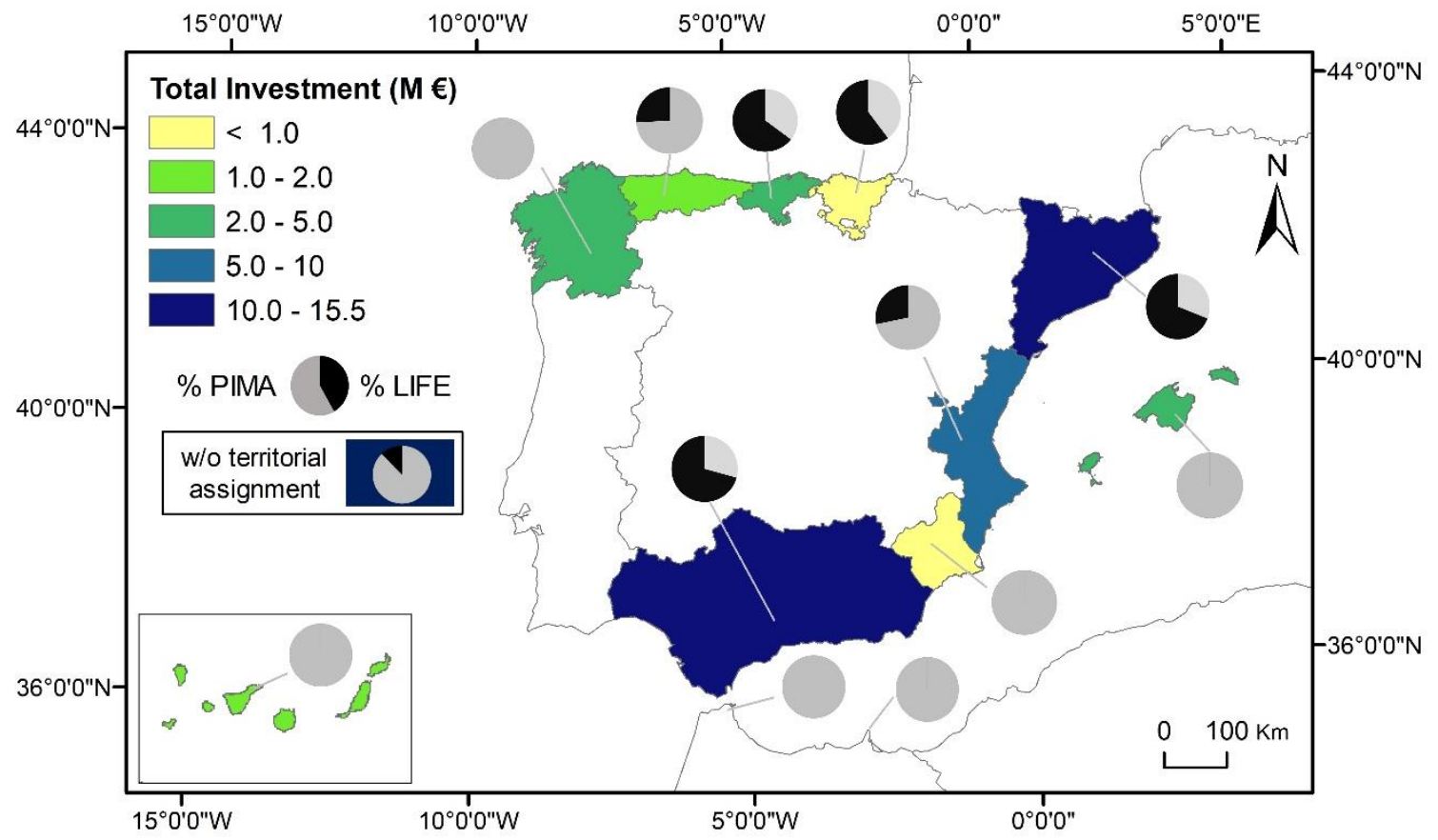

Figure 4. Investment in coastal adaptation to climate change in Spanish coastal regions. Note: 12.8 $\mathrm{M} €$ are destined for general measures without specific territorial assignment. 
A

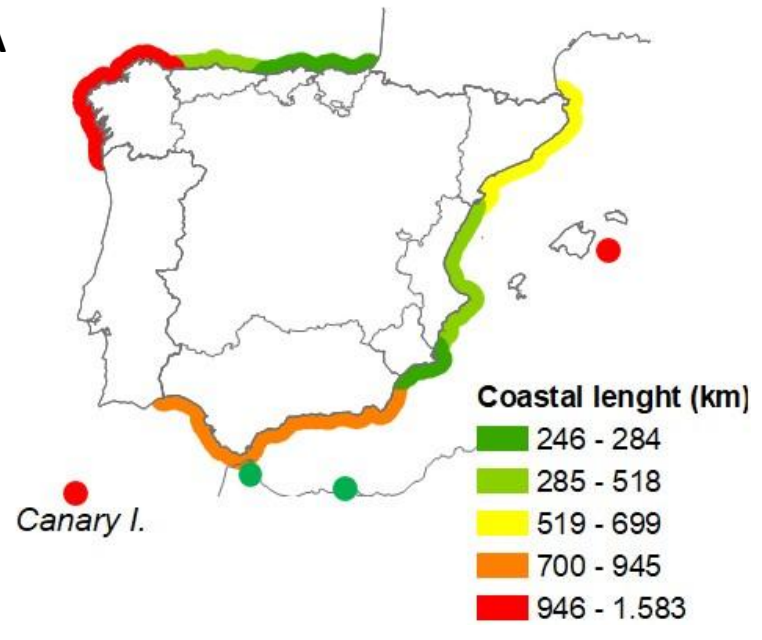

B

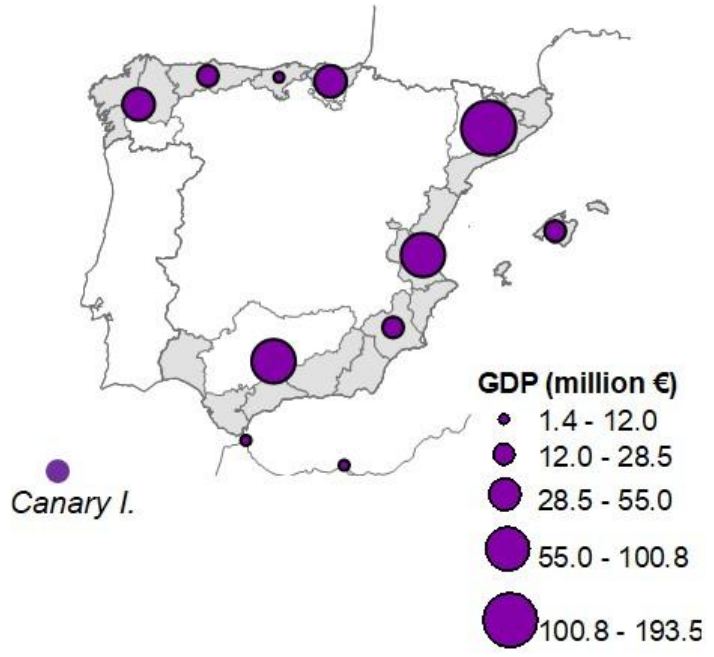

C

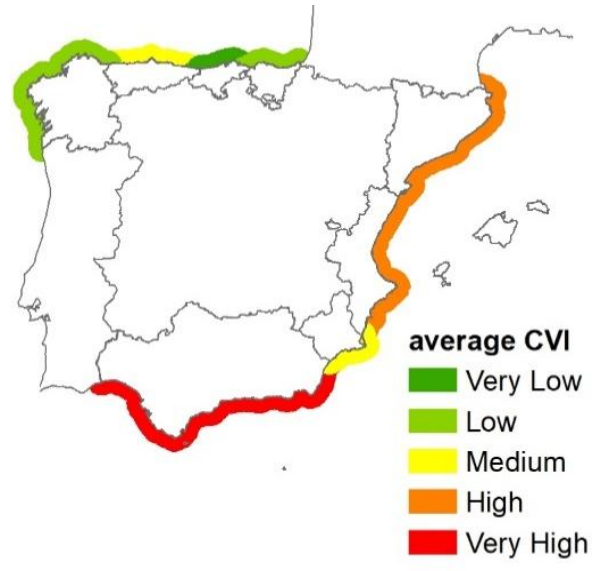

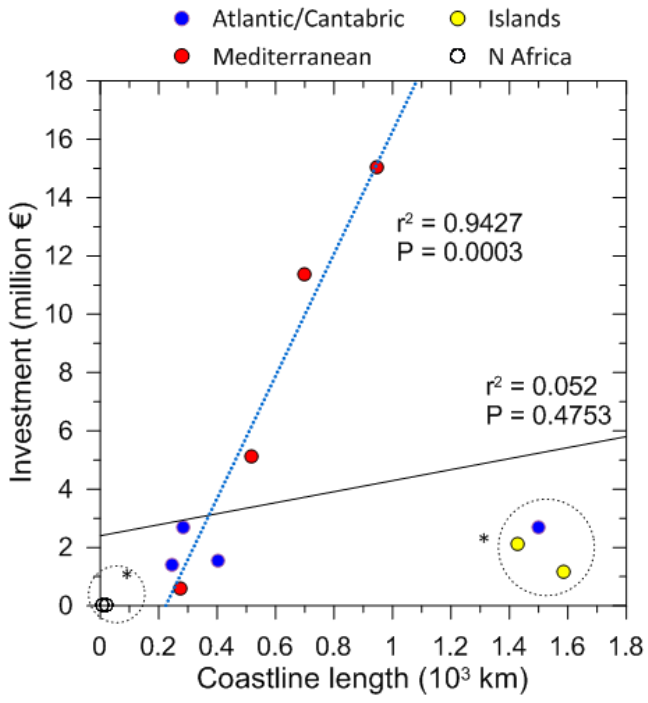

- Atlantic/Cantabric O Islands

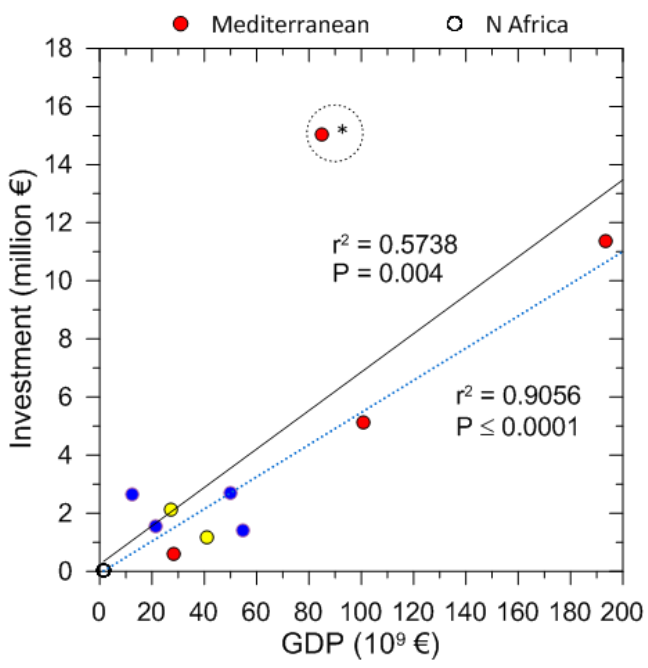

- Atlantic/Cantabric $\bigcirc$ Islands

- Mediterranean O N Africa

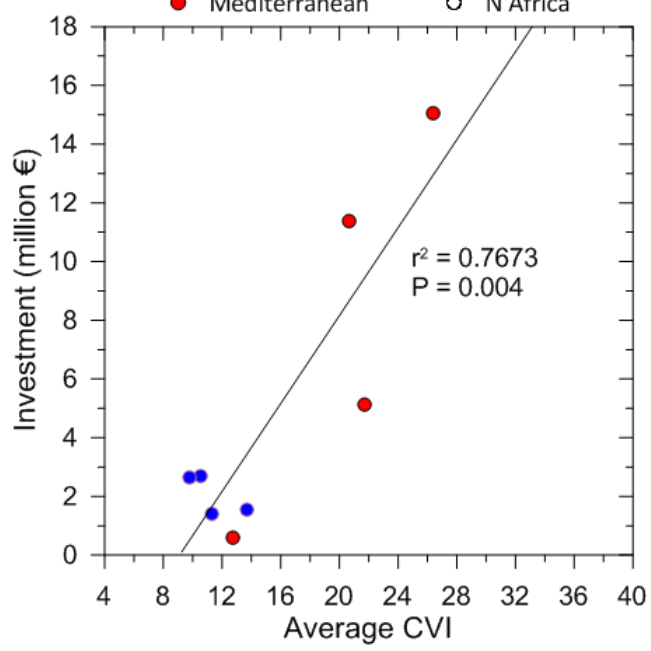

Figure 5. Investment in coastal adaptation per region vs. regional indicators. (A: coastline length; B: GDP of coastal provinces within the region; C: average coastal vulnerability index $(\mathrm{CVI})$ ). (*: indicate excluded values to obtain alternative relationship -blue dashed line-). 


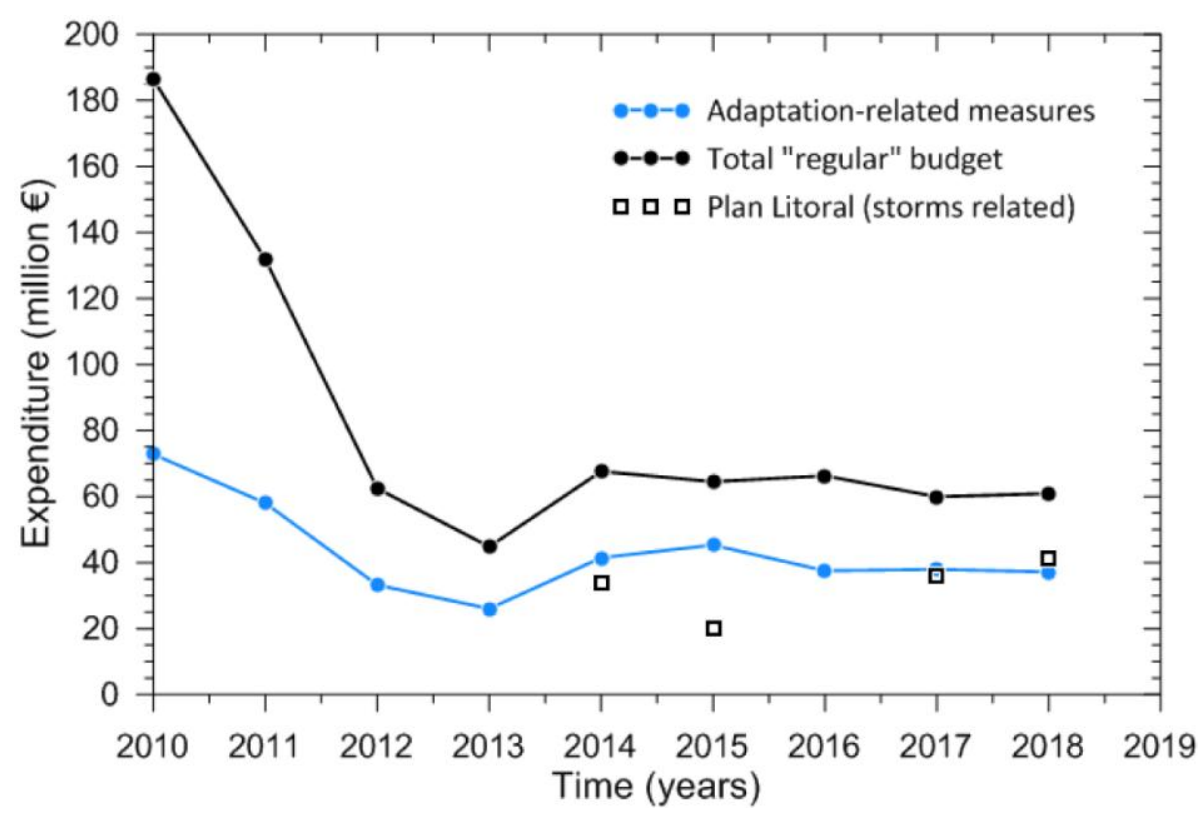

Figure 6. Current expenditures by the General Directorate for Sustainability of the Coast and the Sea (DGSCM) in coastal protection measures. Note: this annual expenditure is referred to as "regular" budget). 


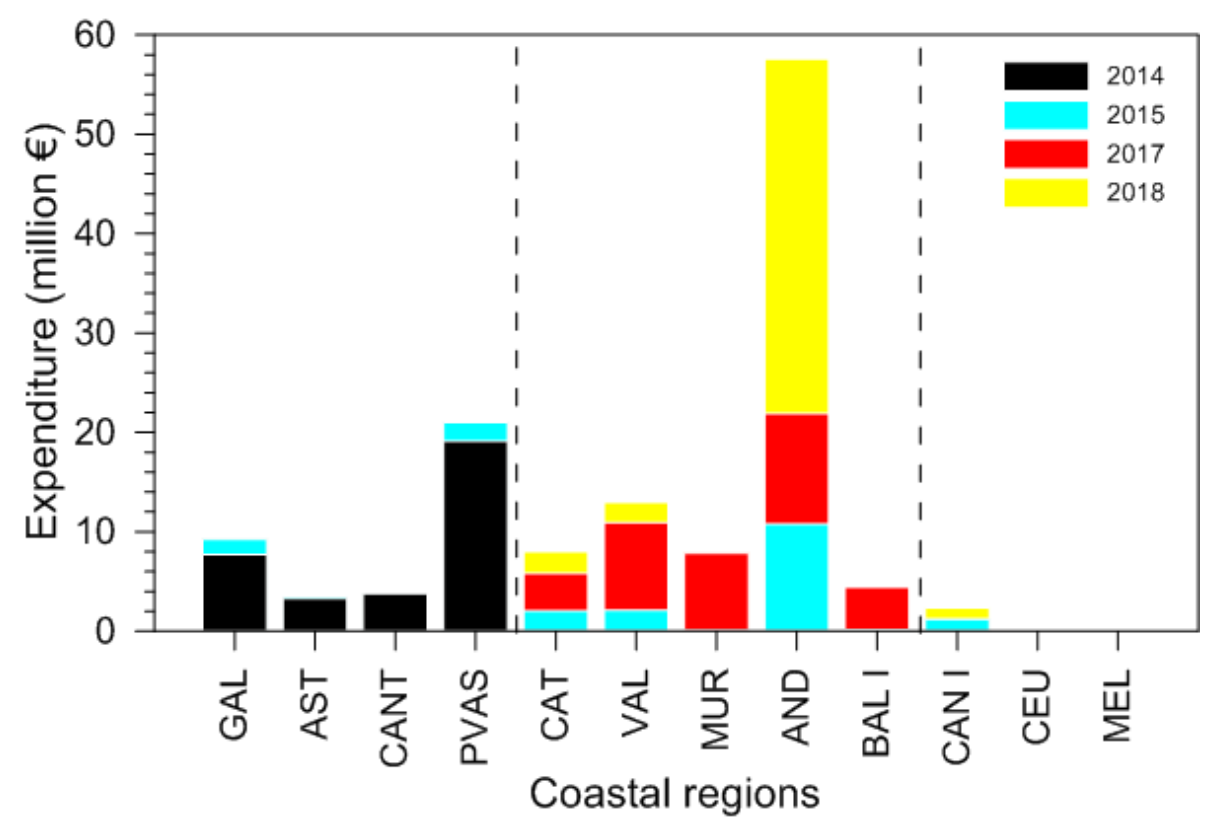

Figure 7. Regional distribution of storm recovery programmes (Plan Litoral). (Location of regions can be seen in Figure 1). 
Supplementary material for on-line publication only
Click here to download Supplementary material for

Click here to download Supplementary material for on-line publication only: Supplementary_material.doc tary material for on-line publication only: Supplementary_material.doc

(1)

tor (1) Click here to download Supplementary 


\section{Declaration of interests}

$\bigotimes$ The authors declare that they have no known competing financial interests or personal relationships that could have appeared to influence the work reported in this paper.

$\square$ The authors declare the following financial interests/personal relationships which may be considered as potential competing interests:

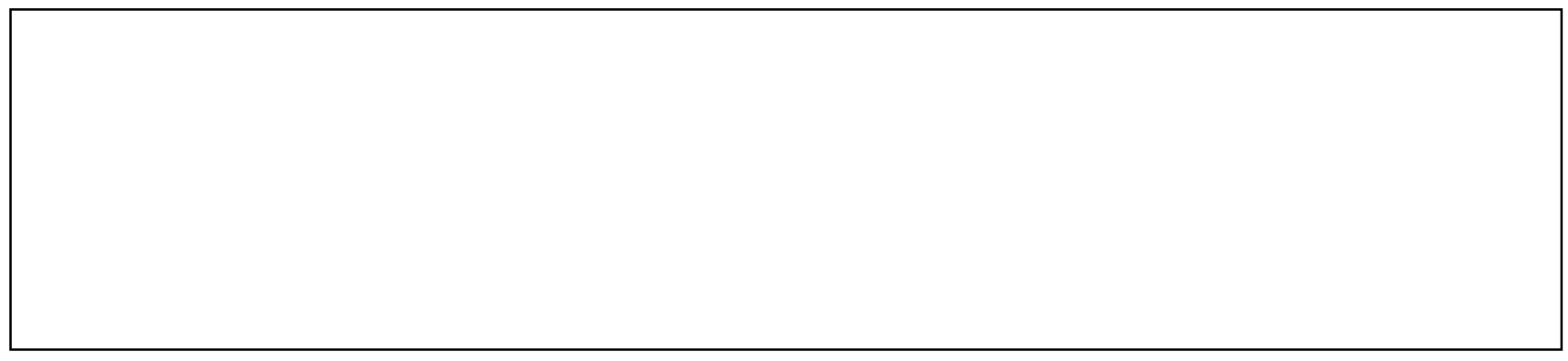

